\title{
约 \\ PLENÁRIOS AO VIVO: UM MAPEAMENTO DAS TRANSMISSÕES DOS PARLAMENTOS DO CONTINENTE AMERICANO
}

\author{
FLOORS LIVE: A BROADCASTING/WEBCASTING MAPPING OF AMERICAN \\ CONTINENT PARLIAMENTS
}

\section{PLENOS EN VIVO: UN MAPEAMENTO DE LAS TRANSMISIONES DESDE LOS PARLAMENTOS DEL CONTINENTE AMERICANO}

\author{
Ginny Carla Morais de Carvalho ${ }^{1}$ \\ Claudia Regina Fonseca Lemos ${ }^{2}$
}

\begin{abstract}
Resumo: O artigo apresenta o mapeamento inédito das transmissões ao vivo, em vídeo, das sessões plenárias dos parlamentos do continente americano, analisadas sob a ótica de estudos acerca de transparência, publicidade e accountability. Os dados obtidos por meio de observação sistemática direta mostram que 51 entre as 55 casas parlamentares nacionais oferecem ao menos uma forma para a população assistir em tempo real as discussões e decisões dos plenários. Considerando a multiplicidade de formatos, estabeleceu-se quatro níveis informativos, que implicam em graus diferenciados de transparência e publicidade. Concluiu-se que a maior parte dos parlamentos do continente ainda necessita qualificar o conteúdo das transmissões, ampliando o compromisso com o entendimento e com o engajamento do público.
\end{abstract}

Palavra-chave: Transmissão ao vivo; Mídias legislativas; Plenário; Poder Legislativo; Parlamentos americanos.

\begin{abstract}
This paper presents an unprecedented investigation of the extent to which national parliaments in the countries of the American continent use live video broadcasts and webcasts of plenary sessions as a means for transparency, publicity and encouraging accountability. Data collected through direct systematic observation of plenary sessions shows that 51 among 55 legislative houses offer at least one means for the public to watch real-time discussions and decisions from the most important arena of the Legislative Branch. Considering the multiple formats offered, we have classified broadcasts in four informative categories, which imply different levels of transparency and publicity. To conclude, for most parliaments there is the challenge of qualifying the information from the live broadcasts of the plenary sessions to broaden understanding, promote greater interactivity and increase the degree of public engagement.
\end{abstract}

Keywords: Broadcasting; Webcasting; Legislative television; Plenary session; Legislative Power.

Resumen: El artículo presenta el mapeo inédito de las transmisiones en vivo, en video, de las sesiones plenarias de los parlamentos del continente americano, analizadas desde la perspectiva de los estudios sobre transparencia, publicidad y rendición de cuentas. Los datos obtenidos a través de la observación sistemática directa muestran que 51 de las 55 cámaras parlamentarias nacionales ofrecen al menos una vía para que la población pueda ver las discusiones y decisiones plenarias en tiempo real. Considerando la multiplicidad

\footnotetext{
${ }^{1}$ Mestre em Poder Legislativo pelo Cefor. Jornalista. Servidora concursada da Câmara dos Deputados desde 2011, com atuação nos veículos de comunicação institucionais. MBA em TV Digital e Novas Mídias pela Universidade Federal Fluminense. E-mail: ginny.morais@gmail.com

2 Jornalista na Secretaria de Comunicação e professora no Mestrado Profissional em Poder Legislativo do Centro de Formação da Câmara dos Deputados. Mestre e doutora em Estudos Literários pela UFMG. E-mail: claudiarflemos@gmail.com
} 
de formatos, se han establecido cuatro niveles de información, lo que implica distintos grados de transparencia y publicidad. Se concluyó que la mayoría de los parlamentos del continente aún necesitan calificar el contenido de las transmisiones, ampliando el compromiso de comprensión y participación pública.

Palabras clave: Transmisión en vivo; Televisión legislativa; Pleno; Poder Legislativo; Parlamentos americanos.

\section{Introdução}

As transmissões ao vivo são vitrines da ação política que se desenvolve nos plenários legislativos. A exposição integral e em tempo real das discussões e decisões está entre as

principais formas de abertura e transparência do Parlamento, sendo considerada também fundamental para o fortalecimento democrático (BEETHAM, 2006; NATIONAL DEMOCRATIC INSTITUTE FOR INTERNATIONAL AFFAIRS, 2007; DECLARAÇÃO PARA A ABERTURA E TRANSPARÊNCIA PARLAMENTAR, 2012; INTERPARLIAMENTARY UNION, 2018; AGORA, 2019).

Este artigo traz parte dos resultados de um levantamento inédito das transmissões em âmbito do continente americano. Os dados foram obtidos a partir da observação direta e sistemática de sessões plenárias, técnica de pesquisa qualitativa que consiste na observação direta dos fenômenos investigados pelos pesquisadores, a partir de critérios previamente definidos (YIN, 2016; PÁDUA, 2019).

Foram consideradas variáveis técnicas para análise da transmissão e criadas categorias qualitativas para classificação de conteúdo (Apêndice A). O corpus do estudo foi composto por todas as 55 casas legislativas dos 35 países autônomos e independentes da região. Foram analisadas 172 sessões, totalizando mais de 670 horas, entre os meses de outubro de 2019 e abril de 2020. A observação foi registrada seguindo uma sistematização de quesitos, em forma de diário de campo digital, que reuniu anotações escritas e fotografias de momentos específicos das transmissões das sessões plenárias.

Os registros foram sistematizados em planilhas eletrônicas e, posteriormente, relacionados com variáveis de ordem política, social, econômica e geográfica. A manipulação de dados foi feita entre junho e julho de 2000). O resultado desse processo são os dados apresentados a seguir.

\section{O plenário que é exposto ao cidadão}

A transmissão ao vivo em vídeo das sessões plenárias é amplamente adotada no continente americano. A pesquisa revelou que $92,7 \%$ das casas parlamentares disponibilizam ao menos um dos formatos considerados - broadcast televisivo ou webcast por sites, plataformas de vídeo on-line (YouTube ou Vimeo) e mídias sociais (Facebook ou Twitter). Cabe destacar os que oferecem todas essas modalidades: parlamentos unicamerais de El Salvador, Peru, Guatemala; câmaras de deputados e senadores do Brasil e do México. No entanto, há legislativos que estão 
no outro extremo: em quatro $(7,3 \%)$ casas legislativas - as duas de Belize e as duas do Haiti - não se constatou nenhuma alternativa para que a população assista às sessões plenárias em tempo real.

O meio mais utilizado para a difusão ao vivo dos atos de plenário no continente é a internet, que vem sendo considerada crucial na expansão do serviço aos cidadãos, pois a tecnologia reduziu custos e facilitou tecnicamente a operação (INTER-PARLIAMENTARY UNION, 2018). O webcast/streaming é disponibilizado por $87,3 \%$ das casas parlamentares americanas. O levantamento mostra que os parlamentos da região decidiram adaptar-se às mudanças de consumo do público, uma vez que em locais onde o acesso à internet é mais amplo, as pessoas estão deixando de ver televisão transmitida de forma tradicional (broadcast) (CANNITO, 2010).

A análise pormenorizada das transmissões ao vivo das sessões plenárias via internet (Gráfico 1) mostra que 31 casas legislativas (56,4\% do total) utilizam o próprio site para tal. Dessas, 13 se utilizam de mecanismos integrados à própria webpage e 18 inserem na página $\mathrm{o}$ link ou o vídeo que, na verdade, está sendo transmitido pelas plataformas privadas de vídeo YouTube e/ou Vimeo.

Quase um terço $(63,6 \%)$ dos parlamentos estudados faz suas transmissões ao vivo em plataformas on-line privadas de vídeo, notadamente o YouTube, que é utilizado por 34 das 35 casas parlamentares que transmitem nesta modalidade. Essa é a opção mais comum de divulgação em tempo real de vídeo das sessões plenárias.

Gráfico 1 - Modalidades de transmissão ao vivo na internet

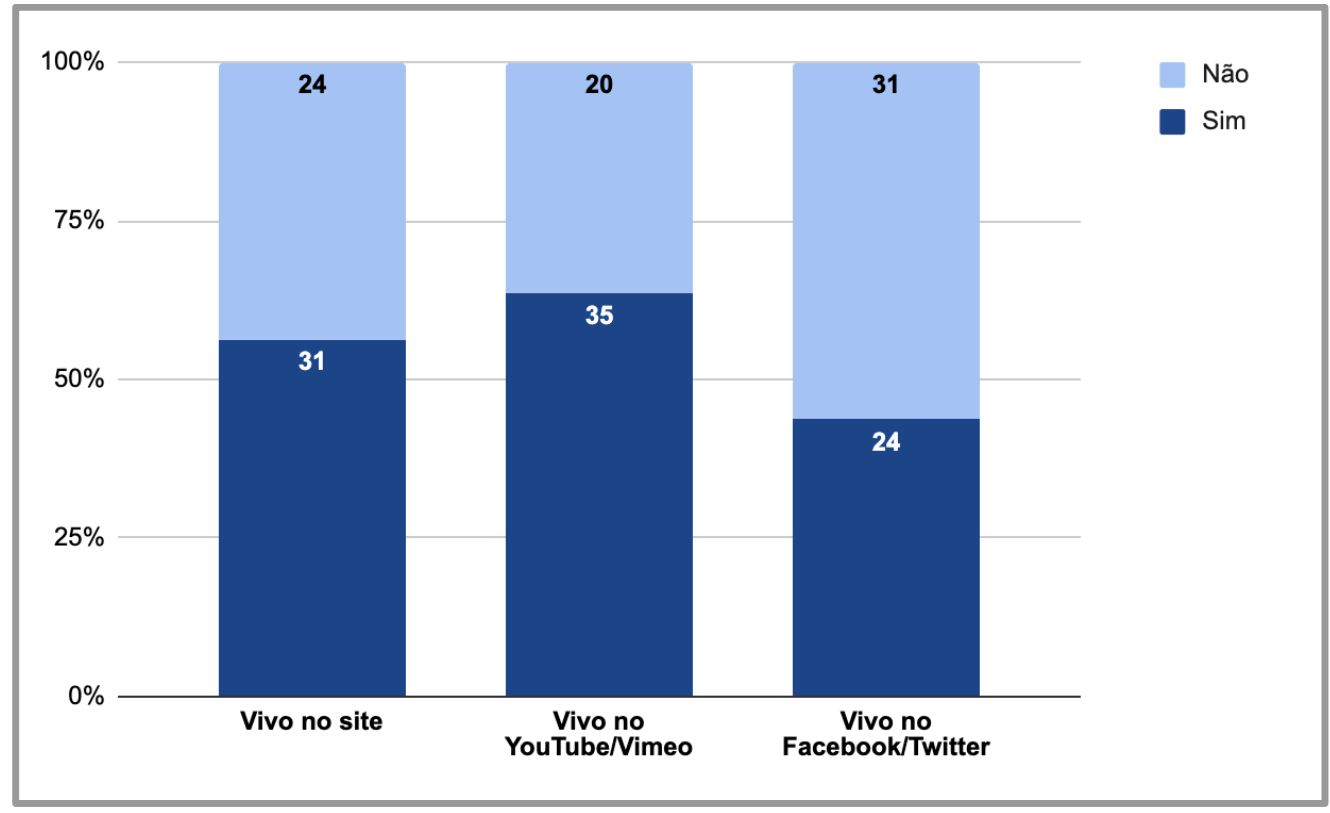

Fonte: Elaboração própria (2020).

Entre as casas legislativas que transmitem a sessão ao vivo pelo YouTube $(61,8 \%$ do total 
de 55), nem todas se utilizam do canal oficial do parlamento na plataforma. Em Dominica e Santa Lúcia, o streaming ao vivo é feito por meio da conta do Governo. Já o parlamento jamaicano tem suas sessões transmitidas pela conta da televisão estatal Public Broadcasting Corporation of Jamaica (PBJC).

Outra estratégia, utilizada por $43,6 \%$ (24) das casas parlamentares pesquisadas, é a transmissão ao vivo por meio do Facebook e Twitter. No continente americano, 69,1\% das casas parlamentares possuem conta no Twitter e o mesmo percentual no Facebook (dados levantados pela pesquisa), percentual próximo do dos parlamentos que globalmente afirmam utilizar mídias sociais: 70\% (INTER-PARLIAMENTARY UNION, 2018). Isso mostra que os legislativos americanos, apesar de seguirem a tendência global de uso das mídias sociais, não adotaram tais mídias majoritariamente como meios de streaming.

É relevante pontuar que, em nível mundial, as mídias sociais são a principal forma de os legislativos se comunicarem com os cidadãos desde 2016, se considerarmos o número de parlamentos que as adotam. Elas estão sendo utilizadas como instrumentos para informar sobre os atos parlamentares, explicar o processo político e legislativo e envolver a sociedade com a instituição (INTER-PARLIAMENTARY UNION, 2018). Tal presença nas mídias sociais vai em busca de atrair um público que está lá pelos mais variados motivos e que tende cada vez mais a consumir informação diretamente nesses ambientes. A expectativa é que esse público possa acabar se interessando pelas informações políticas que são oferecidas (SURYADJAJA, 2016). Enquanto a televisão faz parte de um modelo massivo de comunicação, as mídias sociais integram modelo colaborativo, por envolver maior engajamento (D'ANDRÉA, 2015), embora esse ideal nem sempre se concretize por falta de interação dos parlamentos com os internautas. Além disso, o custo de transmissão por meio da internet e das mídias sociais é bem mais baixo do que o da TV.

A observação direta das sessões revelou que, em algumas casas legislativas, a transmissão ao vivo via mídias sociais é a principal forma de divulgação das sessões plenárias, como na National Assembly de São Cristóvão e Neves, em que o live streaming pelo Facebook é a única opção para quem quer assistir remotamente em tempo real tais eventos. Em outras casas legislativas, o ao vivo via mídias sociais é uma forma adicional de se aproximar do público, complementar à transmissão realizada por televisão, site e YouTube. Tais parlamentos se encaixam na visão de que é preciso multiplicar a presença nos meios de comunicação, pois é por intermédio deles que as pessoas têm acesso a informações que permitem que ajam politicamente (MAIA, 2006).

Fora da internet, a transmissão plenária ao vivo em broadcast televisivo foi verificada em 70,9\% das 55 casas legislativas pesquisadas (Gráfico 2), por meio de emissoras próprias ou de terceiros, em sinal aberto e gratuito ou pago. Pouco mais da metade $(50,9 \%)$ possui canal de televisão especialmente dedicado à divulgação de atividades parlamentares (broadcast via sinal 
aberto ou por assinatura). As chamadas televisões legislativas podem ser de administração própria do Parlamento, como ocorre no Brasil e na Argentina, ou gerida por terceiros, por empresas de TV a cabo (Estados Unidos e Canadá) ou pela corporação de comunicação estatal (Bahamas). São meios de comunicação criados para que o cidadão consuma diretamente da fonte as informações relacionadas ao Legislativo (RENAULT, 2004; SANT'ANNA, 2006), mas também têm o objetivo de influenciar a cobertura noticiosa da mídia privada, que costumeiramente refere-se ao Parlamento de maneira superficial e negativa (SANT'ANNA, 2006). As televisões dedicadas à cobertura de eventos do Poder Legislativo agregam ao cenário informativo a favor da cidadania ao esclarecer as decisões políticas (SANT'ANNA, 2009). Ainda contribuem para a efetividade dos princípios de transparência e publicidade, fundamentais em sistemas representativos (BARROS; BERNARDES; RODRIGUES, 2014), embora sejam palco de constantes conflitos entre as lógicas políticas e jornalísticas (BERNARDES, 2013b).

Gráfico 2 - Comparativo entre transmissão plenária ao vivo em broadcast e webcast

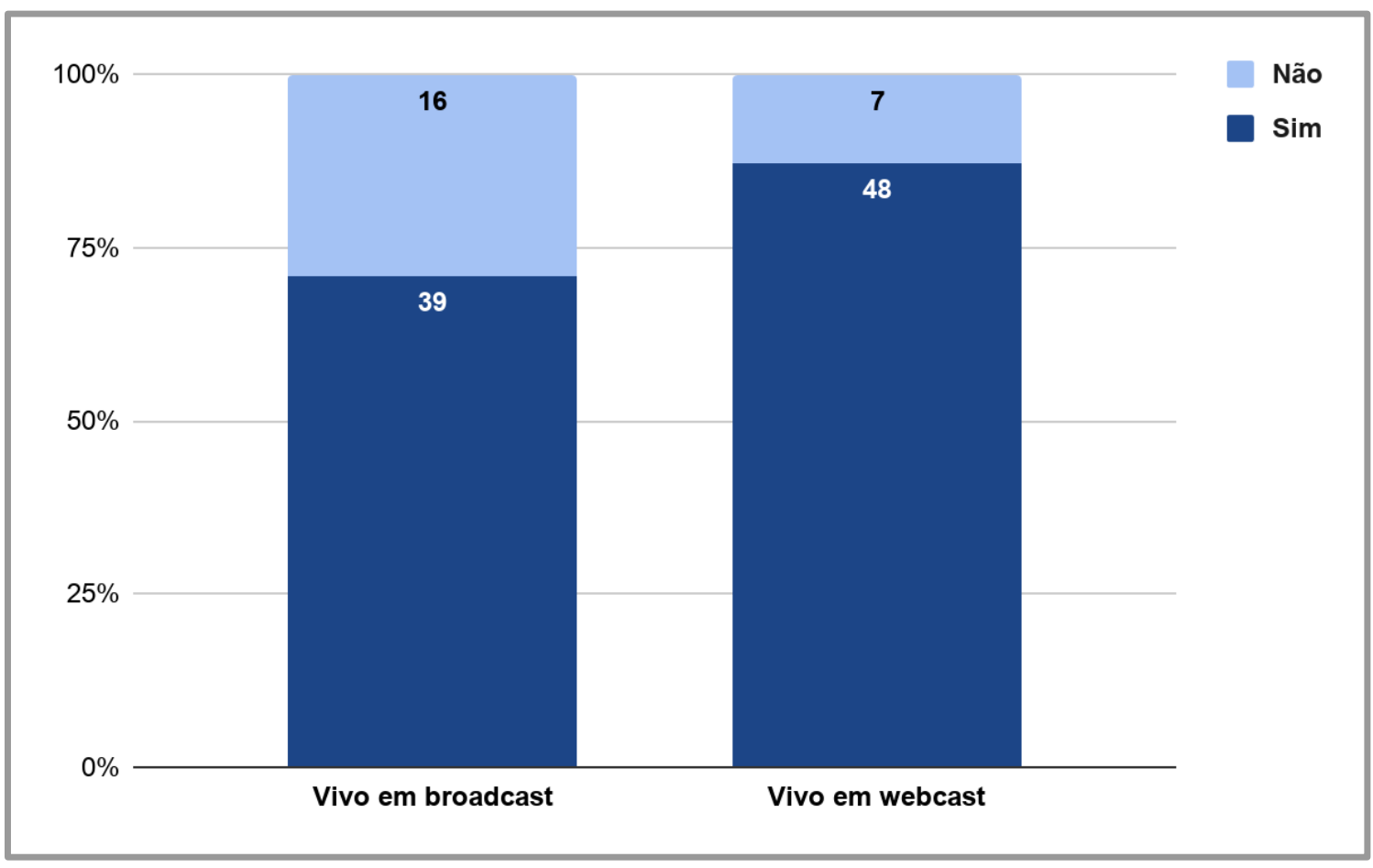

Fonte: Elaboração própria (2020).

A pesquisa mostrou uma realidade um pouco diferente da declarada pelos próprios legislativos à União Interparlamentar. Em 2019, a base de dados da entidade apontava que 61,8\% (34) das casas parlamentares do continente americano possuíam canal de televisão dedicado a transmitir as sessões parlamentares; 23,6\% (13) não possuíam; 14,5\% (8) não haviam disponibilizado a informação. Acredita-se que a diferença entre a situação constatada pelo estudo (50,9\% das casas parlamentares com canais televisivos dedicados) e a registrada na União Interparlamentar $(61,8 \%)$ possa ser explicada pelo fato de alguns parlamentos realizarem apenas 
transmissões ao vivo pela internet de eventos específicos, como as próprias sessões plenárias, sem disponibilizar programação adicional, e mesmo assim terem considerado isso como um canal televisivo ao declarar informações à União Interparlamentar. A divergência também pode ter como justificativa a limitação de registro da realidade por parte desta pesquisa, já que se trata de um levantamento sobre canais televisivos em países não visitados presencialmente pelas pesquisadoras, ou seja, analisados somente com as informações disponíveis à distância.

\subsection{Quando assistir ao vivo}

Para que a população possa assistir às discussões e decisões dos parlamentares em tempo real, é necessário que tenha conhecimento do dia e da hora em que haverá sessão plenária. Por isso, a pesquisa verificou se os parlamentos do continente americano estão disponibilizando previamente tal agenda em seus sites oficiais. A maior parte oferece tal serviço, mas o que chama a atenção é que 41,8\% ainda não oferecem esse instrumento de transparência.

Novamente, o resultado obtido pela observação direta não confere com as informações repassadas pelos próprios parlamentos americanos à União Interparlamentar. Na base de dados da entidade internacional constava, em março de 2020 , que apenas $10,7 \%$ das casas legislativas não ofereciam a agenda prévia do plenário na internet. A justificativa para a divergência pode estar na quantidade de casas legislativas que não forneceram tal dado para a União Interparlamentar ou que afirmaram divulgar apenas "algumas agendas prévias", o que pode ser feito por meio de notícias ou comunicados, que não têm a periodicidade e o local definidos, critério estabelecido para a observação direta. Também é preciso considerar que os dados foram colhidos em momentos diferentes e os sites são modificados constantemente.

Cabe ressaltar que alguns parlamentos divulgam a agenda de sessões plenárias pelas mídias sociais. No entanto, essa modalidade não foi considerada por esta pesquisa devido à irregularidade da informação, sem periodicidade nem localização definidas. No Facebook e no Twitter, não há sistema de busca nas publicações dentro de cada conta, por isso, é preciso percorrer todas as postagens da timeline até encontrar a informação de agenda. Já no site oficial, há um caminho fixo e pré-determinado onde a agenda está disponível, comumente junto com a pauta de votações. Muitas vezes, essa divulgação já está à vista, na página de entrada do site oficial do parlamento, ou a um clique, cujo link é de fácil localização por parte do público, como em um calendário, ou na palavra "agenda", o que caminha no sentido da transparência clara (FOX, 2008), embora nem sempre a linguagem seja simples o suficiente para uma compreensão mais acessível à população.

Já em outros casos, encontrar a agenda prévia de sessões plenárias não é algo intuitivo e requer conhecimento da estrutura do site, a exemplo do que ocorre na Cámara de Diputados da Bolívia e no Parliament da Guiana, em que a informação consta de um PDF dentro de uma seção específica em que há documentos do processo legislativo. Tal situação se enquadra na definição 
de transparência opaca de Fox (2008), em que há a divulgação dos dados, mas sem serem inteligíveis e acessíveis. E foi o que, de fato, se verificou: geralmente, a linguagem da pauta é rebuscada e técnica, o que limita a compreensão imediata de quem não está familiarizado com os termos e o processo legislativo.

\subsection{O que se vê e se ouve na transmissão ao vivo do plenário}

Já que se trata de uma transmissão ao vivo em vídeo, os principais componentes informativos são as imagens e os sons. Por isso, a captação se impõe como relevante porque tem o potencial de interferir no que as pessoas vão ver e ouvir da sessão plenária, de limitar a transparência, ao estabelecer o que pode ser visto, quando e como (GOMES; AMORIM; ALMADA, 2018). Nas transmissões ao vivo nos legislativos, os procedimentos técnicos de imagem e áudio são cuidadosamente pré-determinados e, muitas vezes, passam pelo crivo de atores políticos, corroborando o conceito de "imagem disciplinada" destacado por Renault (2004) e reforçado por Barreto (2018).

A observação direta realizada por esta pesquisa levou em consideração o controle de imagens e sons veiculados nas transmissões ao vivo das sessões plenárias. Como não foi feita visita presencial a todos os parlamentos que fazem parte do escopo, a análise foi feita a partir do produto que é entregue ao público nessas transmissões.

A partir deste momento, para traçar o perfil das transmissões ao vivo das sessões plenárias dos parlamentos americanos, serão consideradas somente as casas legislativas em que se obteve êxito em analisar tais sessões. Dessa forma, o universo passa a ser composto por 50 casas legislativas (retirando-se, portanto, o Senado das Bahamas, que transmite ao vivo apenas em broadcast, e as câmaras altas e baixas de Belize e do Haiti, que não realizam tal transmissão).

Foram encontrados cinco padrões em relação ao posicionamento, tipo e operação de câmeras durante as transmissões das sessões plenárias. Tais realidades foram categorizadas da seguinte maneira:

- Câmeras fixas 1: Câmeras fixas, automatizadas ou não, com enquadramentos prédefinidos;

- Câmeras fixas 2: Câmeras fixas operadas por profissionais;

- Câmeras fixas e móveis: Câmeras fixas e móveis operadas por profissionais;

- Câmeras móveis 1: Câmeras móveis operadas por profissionais;

- Câmeras móveis 2: Câmeras móveis operadas por profissionais, mas com limitação de enquadramento devido à localização restrita.

Em $60 \%$ das casas legislativas que tiveram sessões analisadas (30) há o uso exclusivo de câmeras fixas para captar as imagens das sessões transmitidas ao vivo (Gráfico 3). Em quase a totalidade dos casos, tais dispositivos são instalados nas paredes do plenário e, por serem equipamentos de pequeno porte, passam praticamente despercebidos nas imagens que vão ao ar. 
No entanto, há diferenças quanto à operação dessas câmeras. O modo mais comum, observado em 50\% das casas parlamentares, é quando há profissional para operar as câmeras fixas em tempo real, promovendo ajustes de foco e enquadramento. Em 10\% dos casos, são câmeras fixas com rígidos enquadramentos pré-determinados, muito provavelmente dispositivos automatizados, pois não são feitos ajustes nas imagens em tempo real.

Gráfico 3 - Câmeras usadas para a captação do vídeo da sessão plenária

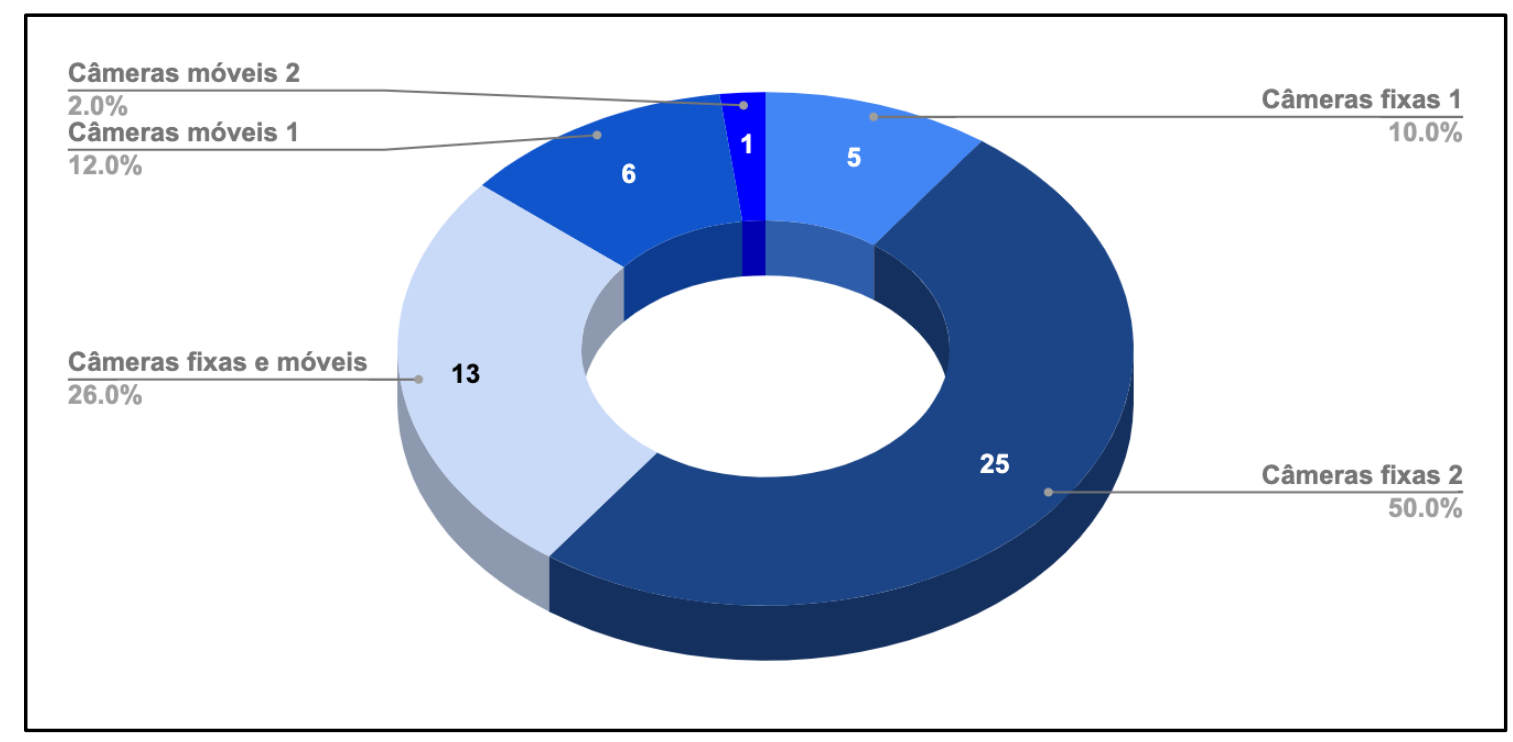

Fonte: Elaboração própria (2020).

Também foi constatado o uso de câmeras móveis para captar as imagens que são transmitidas da sessão plenária. Em alguns casos, esses equipamentos atuam conjuntamente com as câmeras fixas (26\%), possibilitando melhor visualização dos parlamentares que optam por falar de seus lugares no plenário (e não nas tribunas).

Ainda foi registrada a utilização exclusiva de câmeras móveis durante a transmissão ao vivo de sessões plenárias em sete casas parlamentares (14\%). Em apenas uma, na Asamblea Nacional da Venezuela, a câmera ficava em um local restrito da galeria, o que limitava o enquadramento e, por vezes, impedia a visão do rosto de quem estava discursando fora da tribuna. A precariedade na captação de imagens, com a utilização de somente uma câmera móvel, impunha que ajustes como movimentação e zoom para localizar e enquadrar o orador fossem feitos ao vivo, às vistas do telespectador - situação que também foi constatada no Parlamento do Suriname, embora, diferentemente da Venezuela, o cinegrafista estivesse situado dentro do mesmo ambiente que os legisladores no plenário (floor).

A pesquisa também analisou os padrões de enquadramento de imagem em relação à dinâmica da sessão plenária: o que é mostrado ao público enquanto um orador está ao microfone, em quais momentos aparece o plenário como um todo, se há movimentação de câmera e uso de recursos como zoom in e zoom out. Assim como no critério que mapeou de que forma é feita a 
captação por meio de câmeras, o objetivo deste parâmetro é verificar o grau da "imagem disciplinada" (RENAULT 2004; BARRETO, 2018) dessas transmissões parlamentares e de que forma podem limitar a transparência parlamentar em função da maneira como definem o que pode ser visto, quando e como (GOMES; AMORIM; ALMADA, 2018). Até que ponto o que é veiculado mostra o contexto em que as falas e os acontecimentos em plenário se desenrolam?

Há uma imagem-padrão a todas as transmissões das 50 casas legislativas que tiveram sessões analisadas: a que mantém fixa na tela a figura do parlamentar que está com a palavra em meio primeiro plano (da cintura para cima) ou em primeiro plano (do peito para cima). A partir daí, surgem variações que permitem, em maior ou menor grau, observar os pares e ter noção do evento como um todo (Gráfico 4). Foram cinco os padrões verificados em relação a este critério de observação, que foram categorizados da seguinte forma:

- $\quad$ Imagem fixa 1: Imagem fixa no orador, sem mostrar plenário todo;

- Imagem fixa 2: Imagem fixa no orador, com plenário entre as falas e nas votações;

- Imagem fixa 3: Imagem fixa no orador, com plenário entre as falas e nas votações, usando recursos como zoom e movimentação de câmera;

- Imagem intercalada 1: Imagem intercala orador, pares e plenário durante a fala, com planos fixos;

- $\quad$ Imagem intercalada 2: Imagem intercala orador, pares e plenário durante a fala, usando recursos como zoom e movimentação de câmera.

Gráfico 4 - Padrões de enquadramentos de imagens verificados nas transmissões ao vivo

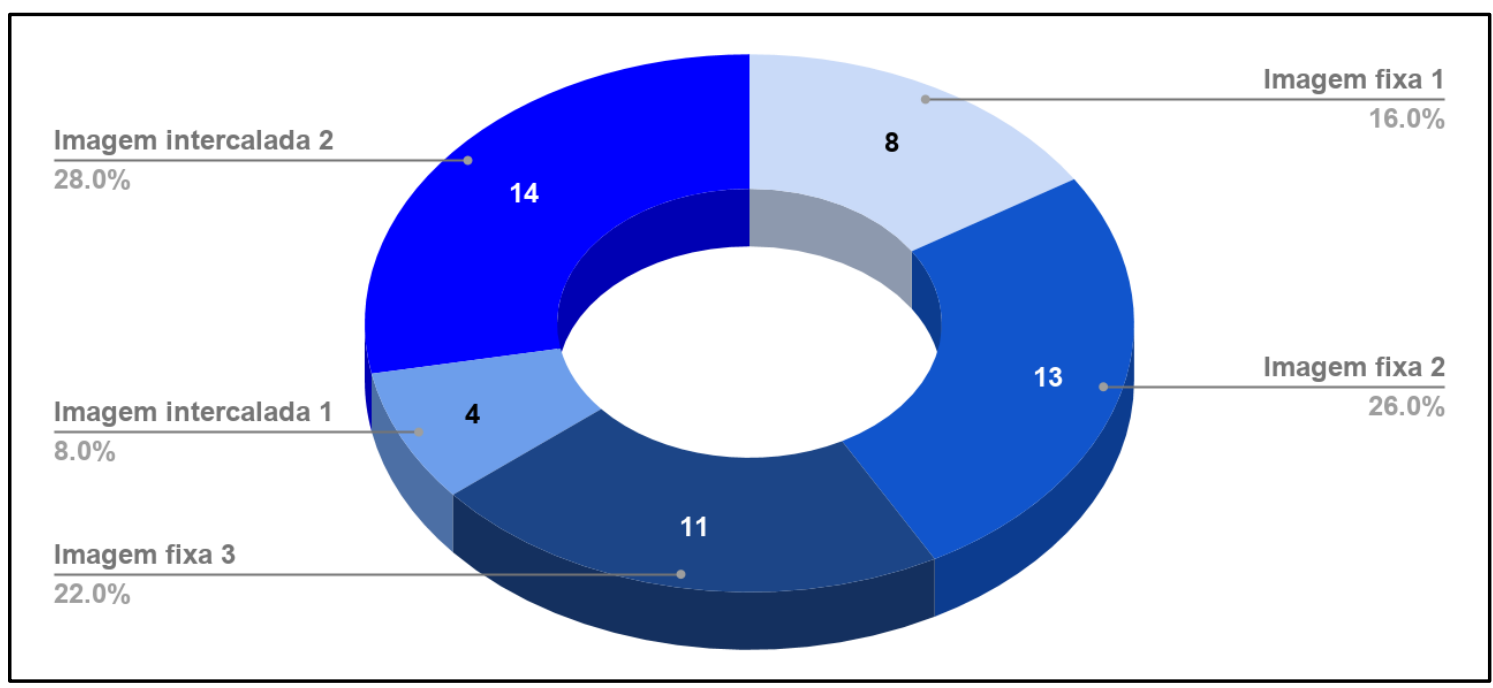

Fonte: Elaboração própria (2020).

Apenas oito (16\%) casas legislativas não mostram o plenário inteiro em nenhum momento da transmissão ao vivo, mantendo o enquadramento das câmeras fechado em parte do plenário (geralmente Mesa Diretora) e/ou no orador do momento. Ainda com enquadramento fixo no parlamentar durante toda a fala, o padrão seguinte avança por usar o plano aberto do plenário na troca de oradores. A visão por completo do plenário ainda é inserida nos momentos de votação. 
Este padrão é o adotado por quase metade (48\%) das casas legislativas americanas que tiveram sessões analisadas, o que demonstra a predominância de procedimentos que vetam a variação de imagens e impõem que apenas o orador é quem deve estar na tela. Esse grupo pode ser subdividido em dois: entre as transmissões que se aproveitam de recursos como movimentação de câmera e zoom na captação de imagens dos oradores e do plenário (22\%) e os que utilizam apenas enquadramentos estanques $(26 \%)$.

Verificou-se ainda que 36\% das casas legislativas intercalam, durante um discurso, a imagem do orador com a dos demais parlamentares ou com a do plenário inteiro - grande parte (28\%) indo além dos enquadramentos fixos e parados, utilizando-se de recursos como movimentação de câmeras e zoom. Essa variação nas imagens e enquadramentos, além de tornar a transmissão mais dinâmica, se constitui em acréscimo de informações visuais e permite ao público verificar, principalmente, as reações dos demais parlamentares ao que está sendo falado no momento. Em ocasiões mais tensas, é o que possibilita assistir a protestos promovidos no recinto durante a sessão.

A falta de variação de imagens impediu, por exemplo, que o público entendesse o motivo da suspensão da sessão plenária da Cámara de Diputadas y Diputados do Chile em 18 de dezembro de 2019, enquanto eram discutidas regras para elaboração de uma nova constituição. As câmeras se restringiram ao orador enquanto se ouvia gritos de protestos e manifestantes invadiram o pleno. Por outro lado, foi o enquadramento mais aberto das câmeras que possibilitou ao público testemunhar o choque e a indignação da bancada governista frente à traição de um de seus integrantes, Charandass Persaud, ao votar favoravelmente à Moção de Desconfiança do Parliament da Guiana ao Governo, em 21 de dezembro de 2018 (Figura 1). 
Figura 1 - Enquadramentos diferenciados em momentos de reações em plenário na Cámara de Diputadas y Diputados do Chile (acima) e no Parliament da Guiana (abaixo)

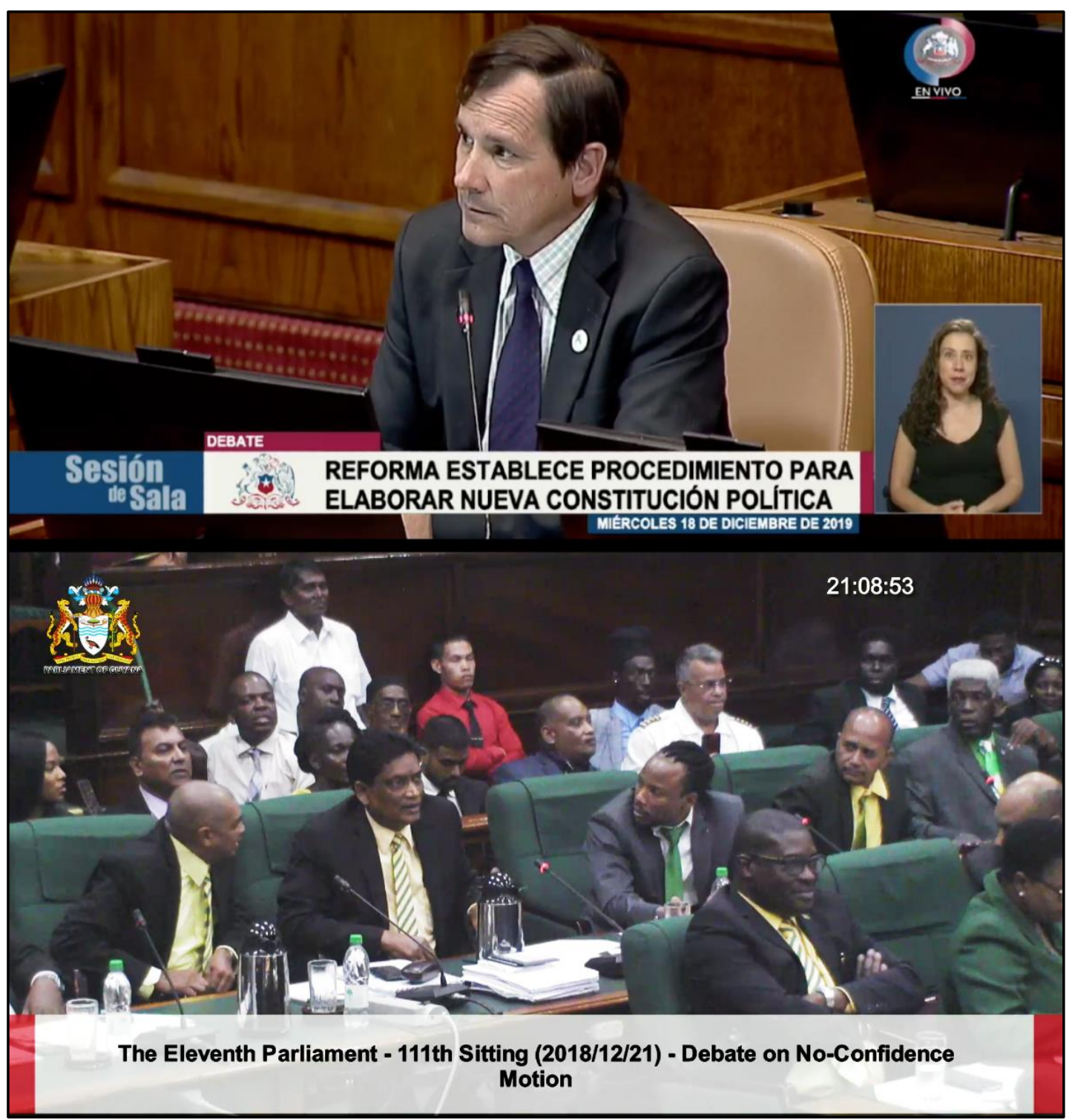

Fonte: Montagem feita a partir de frames captados pelas autoras (2020). Acima, em 25/02/20 de https://www.facebook.com/watch/live/?v=2496567217291691\&ref=watch_permalink. Abaixo, em 29/02/20 de http://parliament.gov.gy/chamber-business/sittings/111th-sitting-eleventh-parliament/

Em relação ao áudio, a observação das sessões plenárias mostrou que quem conduz a sessão tem o poder de dar voz (ou não) aos demais parlamentares. E depende do arbítrio desse ator político, geralmente o presidente da casa legislativa, se as reações e manifestações podem ser ouvidas e registradas pelos equipamentos de áudio e vídeo que fazem a gravação e a transmissão do evento. Em apenas uma casa legislativa, a Asamblea Nacional da Venezuela, se constatou captação de áudio independentemente da decisão da mesa diretora dos trabalhos. E isso só ocorreu porque a captação era precária - ao que tudo indica, das caixas de som do recinto, o que permitiu um alto grau de ambientação. Todas as demais 49 casas legislativas que tiveram sessões analisadas tinham a transmissão ao vivo suprida com áudio captado diretamente do sistema 
institucional de microfones, em que há controle sobre o microfone do parlamentar que está autorizado a falar.

A análise das transmissões indica que quase todas as casas parlamentares têm seus áudios enquadrados em dois grupos: o de parlamentos onde que se consegue ouvir apenas a voz do orador autorizado a falar no momento (32\%) e o grupo em que se escuta prioritariamente o legislador que está com a palavra, mas é possível também ouvir o som ambiente - o que permite perceber reações, mesmo as que não são mostradas em vídeo (situação verificada em $66 \%$ das casas parlamentares). Mesmo onde se verifica esse último padrão de captação de som, foram registrados episódios em que até a ambientação foi cortada, emudecendo totalmente a transmissão durante um período. Tais ocorrências foram verificadas em momentos variados da sessão, como votações, discussões e desrespeitos à fala do orador autorizado, sem que fosse possível identificar uma causa específica.

A pesquisa ainda verificou que duas em cada três (66\%) casas legislativas que tiveram as sessões analisadas não fazem uso de intérpretes de línguas de sinais, para oferecer o conteúdo a pessoas com deficiência auditiva.

\subsection{Que conteúdo a transmissão de plenário oferece}

Este estudo também se dedicou a analisar quais informações estão disponíveis na transmissão ao vivo das sessões plenárias, para além da imagem e do som brutos do evento. Considera-se este um ponto crucial, tendo em vista o desconhecimento e a falta de informação da sociedade em relação ao funcionamento das instituições do Estado e da política (MAIA, 2002; MIXON; UPADHYAYA, 2003; COSSON, 2011). As sessões legislativas possuem ritos próprios e complexos, o que dificulta o entendimento para quem não está habituado a eles. Além disso, tais eventos envolvem, muitas vezes, dezenas e até centenas de legisladores, quantidades que, por si só, impedem o reconhecimento individual de todos os oradores, a não ser que haja uma identificação escrita em tela.

Verificou-se que $80 \%$ das 50 casas parlamentares que tiveram sessões analisadas disponibilizam algum tipo de informação complementar, mesmo que mínima, durante a transmissão ao vivo em vídeo das sessões plenárias. Foram consideradas informações escritas na tela; informações faladas por jornalistas ou locutores sem que apareçam na tela (narração ou voiceover); e informações fornecidas por jornalistas que aparecem na tela durante a transmissão ao vivo. A incidência de cada categoria está no Gráfico 5 a seguir. 
Gráfico 5 - Tipo de informação fornecida na transmissão ao vivo das sessões plenárias

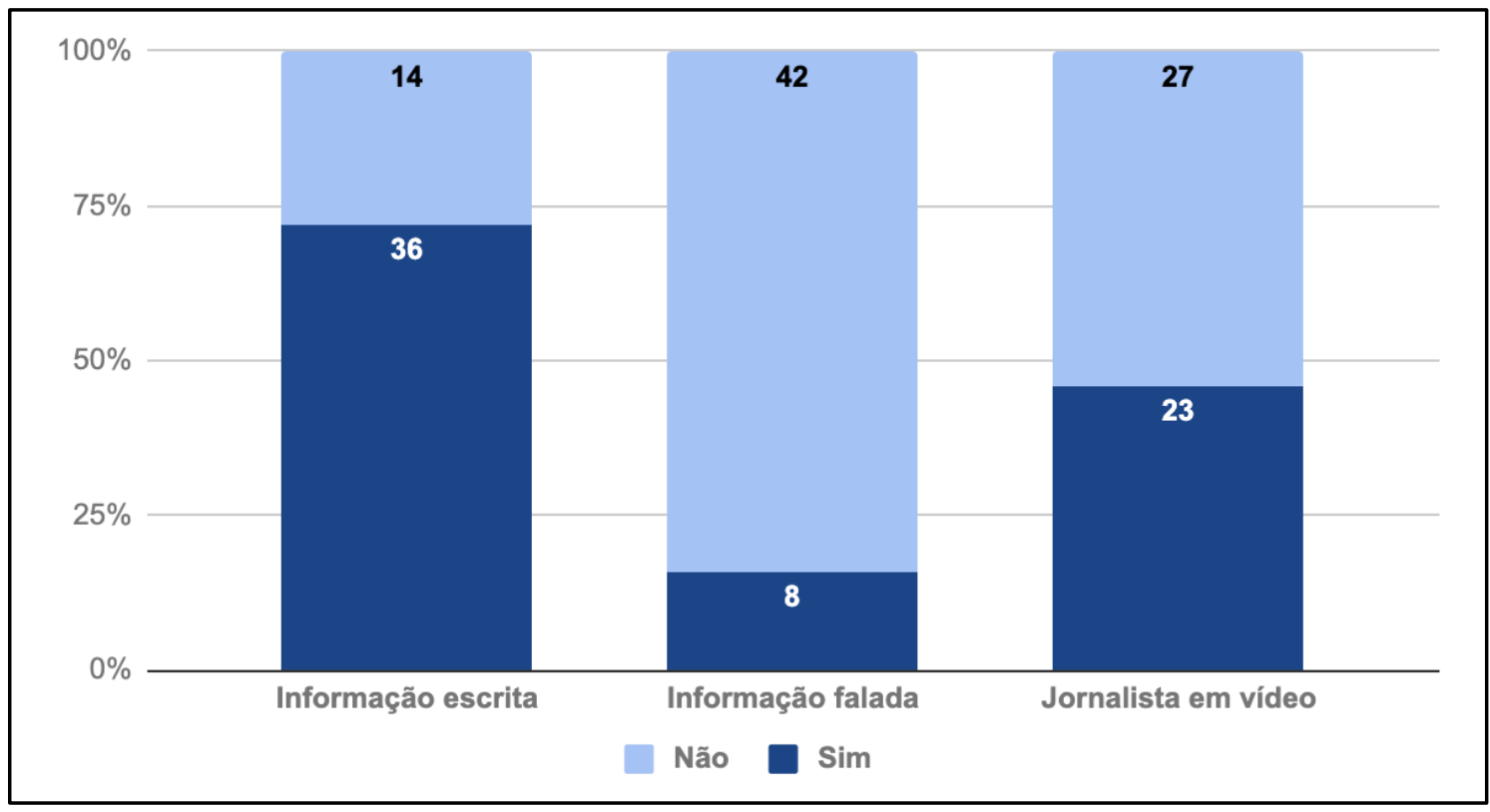

Fonte: Elaboração própria (2020).

O conteúdo escrito na tela é o mais frequente, sendo utilizado por $72 \%$ das casas parlamentares que tiveram sessões analisadas. Essas informações dispostas no vídeo são fundamentais para a identificação do parlamentar que está com a palavra, como o nome, o cargo, o estado e o partido. Também entram dados que indicam em que fase a sessão se encontra, o número do projeto que está em debate ou em votação e explicações adicionais sobre o tema em questão.

Quase metade (46\%) das casas legislativas insere jornalistas ou comunicadores na tela ao longo da transmissão ao vivo. Esses profissionais explicam e fazem o resumo das propostas que estão em pauta ou foram deliberadas, além de entrevistarem parlamentares em alguns casos. Atuam segundo premissas da subcategoria do jornalismo político, a de "jornalista legislativo" (FREITAS, 2020), entre elas, a de ter conhecimento especializado na área, mas, ao fazer as intervenções, se limitar a transmitir relatos, processar as informações o mais rápido possível, sem emitir opinião, com vistas ao interesse público (MALAVAZI, 2004; SANT'ANNA, 2009; FREITAS, 2020). Já a informação apenas falada, que oferece uma narração sobre a imagem do plenário, também trazendo explicações acerca das propostas e do processo legislativo, é a menos utilizada pelos parlamentos - foi verificada em apenas $16 \%$ das casas legislativas.

As informações escritas inseridas na transmissão ao vivo das sessões plenárias são as que têm menor potencial invasivo em relação ao andamento do processo legislativo, pois não impõem interferência na visão ou escuta dos parlamentares. Ruídos podem ocorrer quando a explicação é dada por jornalistas (aparecendo ou não na tela). As informações escritas também são de utilização relativamente simples, podem ser inseridas remotamente (fora da sede do parlamento) 
e usar os mesmos moldes, padrões e softwares já comumente utilizados pelas transmissões televisivas dos canais generalistas, em especial, os jornalísticos.

Quanto ao momento de inserção, geralmente as informações escritas são verificadas ao longo de toda a transmissão ao vivo, ao contrário das demais categorias de informações analisadas por esta pesquisa ("explicações faladas" e "jornalistas em vídeo") que, quando incidentes, costumam se restringir ao antes e após o período oficial das sessões.

É preciso levar em conta que, além do conteúdo escrito ser restrito ao limitado espaço da tela, informações orais (com ou sem a imagem do jornalista em tela) têm potencial de serem mais didáticas ao público, considerando a possibilidade de contextualização de assuntos legislativos complexos que necessitam de assimilação simultânea ao acontecimento.

O público difuso das transmissões ao vivo também aumenta a necessidade de explicação dos fatos (MAIA, 2002). Isso é especialmente importante no contexto latino-americano, que compreende a maior parte dos países integrantes do escopo desta pesquisa, território em que, segundo Martín-Barbero (1997), a oralidade é predominante na cultura e na comunicação popular.

Apesar disso, pouco mais da metade (52\%) das casas parlamentares não oferece nenhum tipo de informação falada ou fornecida por jornalista aparecendo em vídeo durante toda a transmissão ao vivo (Gráfico 6). Entre as que oferecem (48\%), grande parte o faz antes da abertura regimental da sessão plenária e/ou após o encerramento oficial, o que mostra a disponibilidade de recursos técnicos e humanos para agregar explicações orais ao longo do evento, mas um forte respeito à liturgia e aos discursos parlamentares, que atua como limitador para tais inserções, de modo a não haver perigo de interferência na fala dos representantes. Tal constatação se enquadra no que Barreto (2018) chamou de "parlamentarização da mídia", que é uma resistência dos procedimentos políticos frente aos padrões estéticos e às narrativas midiáticas.

Gráfico 6 - Inserção de informação falada ou jornalista em vídeo

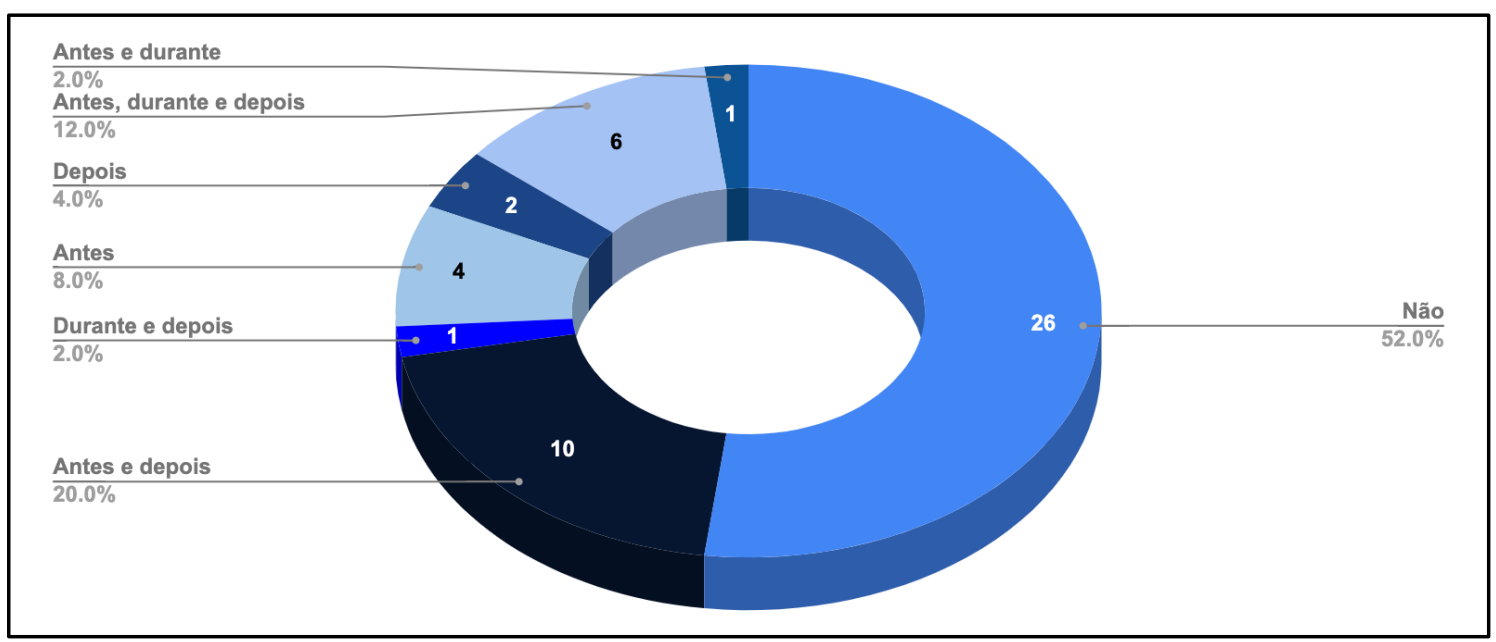

Fonte: Elaboração própria (2020). 
Apenas em oito (16\%) casas parlamentares verificou-se a ocorrência de explicações orais, com ou sem a presença do jornalista em vídeo, durante o período regimental da sessão plenária. Em todas essas, as intervenções ocorreram tão somente nas pausas entre as falas parlamentares (entre discursos, em silêncios para votações e nas suspensões de sessão), ou seja, com interferência mínima na liturgia parlamentar. No geral, observou-se que o objetivo era esclarecer termos técnicos e ritos processuais, além de contextualizar assuntos que estavam em debate ou votação naquele determinado momento. Mais uma vez, o que se verificou é que profissionais (jornalistas e locutores) atuam para reunir dados, processá-los e transmiti-los sem emissão de opinião (SANT'ANNA, 2009).

\subsubsection{Informações escritas na tela}

Pouco mais de um quarto das casas parlamentares (28\%) não disponibiliza nenhuma informação escrita ao longo da transmissão ao vivo das sessões plenárias, sequer os nomes dos que estão discursando ao microfone, como é o caso do Senado boliviano. Isso deixa o público sem informações elementares da política parlamentar, que são a identidade dos atores e a base eleitoral que representam.

São 36 as casas parlamentares que incluem informações escritas ao longo das transmissões ao vivo das sessões plenárias (72\% do universo de parlamentos em que foi possível analisar as transmissões). Para distinguir qualitativamente os dados dispostos na tela, criou-se uma escala de acordo com o tipo de informação disponibilizada e a linguagem oferecida. As gradações estabelecidas foram:

- $\quad$ Nenhuma: nenhuma informação é inserida na tela;

- Incipiente: há apenas a identificação do orador (nome, partido, base eleitoral etc);

- Razoável: há a identificação do orador e o tema/projeto em discussão ou votação, em linguagem técnica (com letras, números e ementa);

- Boa: há a identificação do orador e o tema/projeto em discussão ou votação, em linguagem simples e clara (plain language la $^{3}$;

- Muito boa: há a identificação do orador, o nome/número do projeto em discussão ou votação e explicações adicionais (quórum, fase em que a sessão se encontra etc), com elementos em linguagem simples e clara (plain language).

\footnotetext{
3 Plain language é um movimento internacional que defende a comunicação com linguagem simples e clara, que permita ao público "entender na primeira vez que lê ou escuta", segundo definição da Rede de Ação e Informação em Linguagem Simples (Plain Language Action and Information Network), órgão vinculado oficialmente ao Governo dos Estados Unidos (2019).
} 
Em 30\% das casas legislativas que tiveram as sessões analisadas foi verificada a oferta somente de informações básicas para o reconhecimento dos parlamentares que estão com a palavra, geralmente nome, partido e local da base eleitoral (Gráfico 7). Duas (4\%) adicionam a isso a denominação técnica do projeto no momento da votação, dado muitas vezes inteligível por ser formado por letras e números, o que limita o entendimento no sentido de promover publicidade (FILGUEIRAS, 2011), e se torna um exemplo de transparência opaca, que em há a informação, mas que não revela o real sentido do ato político (FOX, 2008). Em 12\% das casas parlamentares há um avanço no sentido de tornar mais compreensível o que está em votação - há inserção de informações escritas em linguagem simples sobre a proposição. Cabe ressaltar que, em alguns legislativos, os nomes dos oradores e os dados acerca das propostas ficam dispostos na tela somente alguns segundos, mesmo em longos discursos.

Gráfico 7 - Incidência de informação escrita durante transmissão ao vivo

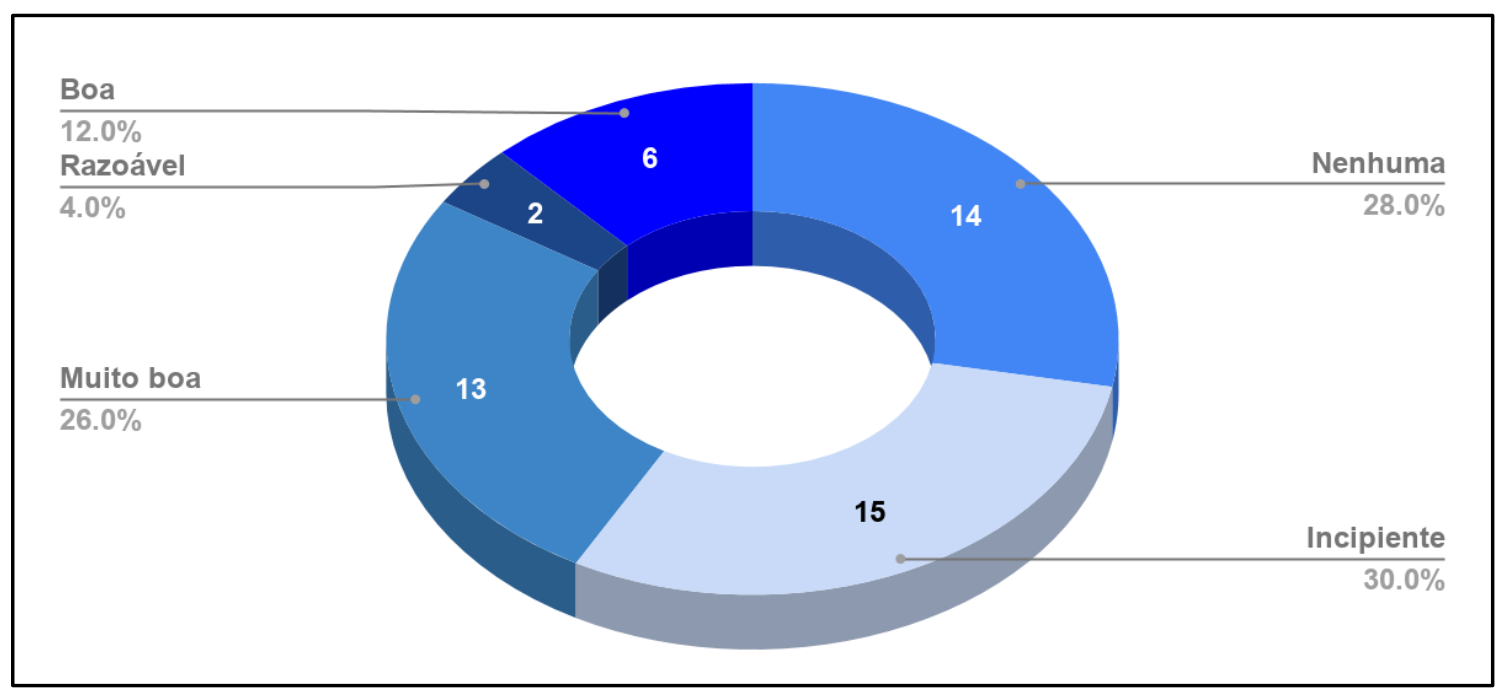

Fonte: Elaboração própria (2020).

A disponibilização de diversas informações para identificação do legislador e para entendimento da sessão e da proposta em debate ou em votação (categoria "muito boa") foi verificada em $26 \%$ das casas parlamentares que tiveram sessões analisadas por esta pesquisa. Apesar de esses legislativos terem sido classificados em um mesmo grupo, os formatos informativos são tão diferenciados que não é possível afirmar que exista um padrão quanto à frequência e permanência dos dados em tela, nem quanto à variedade de explicações disponibilizadas ou à linguagem (buscou-se a simplicidade e a clareza exigida pela plain language $^{4}$, mas isso não foi verificado em todos os casos do grupo e nem mesmo em todas as ocasiões de uma mesma sessão plenária). O fato é que, ao longo da transmissão, são fornecidas

\footnotetext{
${ }^{4}$ Plain language é um movimento internacional que defende a comunicação com linguagem simples e clara, que permita ao público "entender na primeira vez que lê ou escuta", segundo a Rede de Ação e Informação em Linguagem Simples (Plain Language Action and Information Network), vinculada ao Governo dos Estados Unidos.
} 
informações além das consideradas nas categorias anteriores (nome, partido, distrito e proposição), o que oferece melhor contextualização e pode possibilitar um entendimento mais amplo do evento parlamentar.

Em alguns parlamentos da categoria "muito boa", as informações escritas ficam presentes na tela durante toda a transmissão, com a tarja informativa sendo modificada constantemente, o que possibilita a inclusão de mais dados. Isso foi verificado, por exemplo, na Asamblea Nacional do Equador e na Câmara dos Deputados do Brasil.

\subsubsection{Mediação jornalística em tela}

A presença de jornalistas na tela em pelo menos uma oportunidade ao longo da transmissão ao vivo das sessões plenárias foi verificada em 46\% (23) das casas legislativas. O comunicador geralmente aparece no vídeo para fornecer explicações sobre os assuntos envolvidos no evento parlamentar e/ou para entrevistar legisladores. Atua como uma espécie de tradutor da liturgia e da linguagem específica, um facilitador de entendimento (MAIA, 2002) entre o Legislativo e os cidadãos, um agente que seleciona conteúdo e constrói nexo (MARTíNBARBERO, 1997).

Neste quesito, o resultado da observação sistemática direta desta pesquisa pode ser dividido sob dois pontos de análise. O primeiro, é quanto ao momento da intervenção jornalística ao vivo (Quadro 1). Esse aspecto é relevante porque revela o tipo de conteúdo que está sendo levado ao público. Antes de a sessão iniciar, o jornalista pode falar da pauta do dia, contextualizando o debate político e explicando as propostas que podem vir a ser deliberadas pelos parlamentares. Trata-se de uma expectativa, que, no desenrolar dos fatos, pode não se cumprir. Durante o andamento da sessão plenária, as explicações feitas por jornalistas permitem o entendimento simultâneo ao acontecimento. Entende-se que é uma inserção relevante devido à especificidade dos procedimentos, normas e linguagens próprios do processo legislativo, comumente remissivos a legislações já existentes, o que impede a compreensão instantânea até mesmo de quem atua na área. Além disso, as sessões plenárias, muitas vezes, não têm uma discussão linear, com temas "indo e voltando" entre os oradores, intercalados com outros assuntos - o que pode não fazer muito sentido para quem não é habituado a tal dinâmica. Também por isso, sustenta-se que a presença de um jornalista fazendo as conexões e explicando as regras regimentais pode contribuir para o esclarecimento de questões técnicas ao público leigo e para a compreensão prática dos atos legislativos e dos debates enquanto estão sendo travados. Já após o encerramento da sessão, o jornalista faz o resumo do evento, fala de um fato consumado - o que os parlamentares debateram/decidiram ou não. Pode até repercutir esse resultado em entrevistas com os legisladores e abordar possíveis desdobramentos, mas que não se darão mais naquele tempo e lugar.

Verificou-se que $36 \%$ das casas parlamentares têm jornalistas aparecendo no vídeo, mas 
somente fora do período regimental das sessões plenárias, ou seja, antes e/ou depois da abertura e do encerramento oficial de tais eventos. Em apenas 10\% das casas legislativas o profissional aparece na tela também ao longo do ritual regimental da sessão plenária.

O momento em que é feita a mediação jornalística na transmissão ao vivo de plenário é relevante sob a ótica da transparência, publicidade e accountability, ou seja, levando em consideração o que o cidadão tem potencial de fazer com tais informações ao tempo em que passa a ter conhecimento delas. Há possibilidade de empoderamento popular e de grupos de interesse específicos, que, em um contexto político-social cada vez mais conectado virtualmente, podem pressionar parlamentares pela internet e alterar o curso previsto para determinada sessão plenária. As informações fornecidas por jornalistas antes e durante as transmissões ao vivo das sessões plenárias reforçam a possibilidade de reações imediatas da sociedade, como "tuitaços", votações em enquetes online, envio massivo de mensagens direcionadas a determinado parlamentar e até mesmo ações presenciais (passeatas, reuniões de pessoas em um determinado lugar etc.). Essas mobilizações se inserem no contexto de aumento de cobrança social que veio com o avanço das tecnologias de informação (FILGUEIRAS, 2011). Podem repercutir na arena política e adiar uma votação, por exemplo, o que se enquadra no conceito de transparência in fieri, em que uma política pública é disponibilizada para deliberação antes de ser implementada (GOMES; AMORIM; ALMADA, 2018). Os resumos jornalísticos feitos após o encerramento da sessão têm potencial de impulsionar as mesmas reações populares, porém os efeitos podem não ser os mesmos, especialmente nos casos em que uma votação já tenha sido concluída.

Por mais que a mediação jornalística aponte para uma agregação de informação e entendimento, é preciso fazer a ressalva de que as iniciativas são muito variadas quanto à duração e aos conteúdos oferecidos. Assim, não é possível afirmar que a atuação de profissionais de comunicação sempre torna a transmissão mais inteligível para o cidadão. Isso porque há casos entre os estudados em que o jornalista traz explicações somente antes ou depois da sessão plenária e enquanto o rito legislativo se desenrola nenhuma informação adicional é inserida, nem ao menos a indicação escrita do nome do parlamentar que está com a fala. Isso foi verificado nas casas legislativas da Jamaica, Santa Lúcia e Venezuela. 
Plenários ao vivo: um mapeamento das transmissões dos legislativos do continente americano

Quadro 1 - Momento da intervenção jornalística

\begin{tabular}{|c|c|}
\hline $\begin{array}{c}\text { Momento da } \\
\text { intervenção jornalística }\end{array}$ & Casa parlamentar \\
\hline \multirow{5}{*}{ Somente antes da sessão } & Colômbia - Cámara de Representantes \\
\hline & Equador - Asamblea Nacional \\
\hline & Jamaica - House of Representatives \\
\hline & Jamaica - Senate \\
\hline & Nicarágua - Asamblea Nacional \\
\hline \multirow{9}{*}{ Antes e depois da sessão } & Argentina - Senado \\
\hline & Bahamas - House of Assembly \\
\hline & Chile - Senado \\
\hline & Cuba - Asamblea Nacional del Poder Popular \\
\hline & El Salvador - Asamblea Legislativa \\
\hline & Honduras - Congreso Nacional \\
\hline & Santa Lúcia - House of Assembly \\
\hline & Santa Lúcia - Senate \\
\hline & Venezuela - Asamblea Nacional \\
\hline \multirow{4}{*}{ Antes, durante e depois da sessão } & México - Cámara de Diputados \\
\hline & México - Senado \\
\hline & Panamá - Asamblea Legislativa \\
\hline & Peru - Congreso de la República \\
\hline Durante e depois da sessão & Brasil - Câmara dos Deputados \\
\hline \multirow{4}{*}{ Somente depois da sessão } & Chile - Cámara de Diputadas y Diputados \\
\hline & Costa Rica - Asamblea Legislativa \\
\hline & Estados Unidos - Senate \\
\hline & Guatemala - Congreso \\
\hline
\end{tabular}

Fonte: Elaboração própria (2020). 
O segundo ponto de análise ao qual deve ser submetido o levantamento sobre a mediação jornalística nas transmissões ao vivo das sessões plenárias refere-se à localização física do profissional quando aparece no vídeo, pois influencia diretamente na informação a que o comunicador tem acesso no momento e, por consequência, interfere nas explicações que repassará para o público. Jornalistas que estão fora do plenário ou em estúdio geralmente acompanham a sessão por meio das imagens captadas pelas câmeras - ou seja, não possuem visão do plenário como um todo não têm como perceber e ter acesso a acontecimentos que se desenrolam fora do enquadramento dado pelas lentes, como conversas entre líderes partidários, protestos de parlamentares que não estão ao microfone, provocação vinda das galerias, entrada e saída de legisladores do recinto etc.

Já o repórter que está dentro do plenário, mesmo com mobilidade restrita - limitado às galerias ou em local destinado à imprensa -, é testemunha ocular da sessão plenária como um todo. E quanto mais livre for sua circulação, mais acesso terá à informação, pois poderá conversar com assessores e parlamentares, inclusive, entrevistá-los ao vivo. A presença física no mesmo ambiente da ação legislativa é, com certeza, um diferencial relevante na mediação jornalística.

Na Figura 2, estão dispostos exemplos das principais localizações de entradas ao vivo de jornalistas durante transmissões ao vivo de sessões plenárias. Acima, à esquerda, é o registro do momento em que a profissional, por estar dentro do plenário e perto da Mesa Diretora, consegue abordar para uma entrevista o presidente da Asamblea Nacional da Venezuela, Juan Guaidó, no final da sessão ordinária do dia 29 de outubro de 2019. Acima, à direita, está a imagem da repórter que faz o resumo das votações do dia 17 de setembro de 2019 direto da galeria do plenário da House of Assembly de Santa Lúcia. Abaixo, à esquerda, o profissional explica, do lado de fora do plenário, o que está previsto na pauta da sessão do Senado chileno do dia 6 de janeiro de 2020, que está prestes a começar. E abaixo, à direita, o jornalista explica, em estúdio, o que foi decidido até o momento de suspensão da sessão do parlamento cubano no dia 21 de dezembro de 2019. 
Figura 2 - Registros de inserções de jornalistas no vídeo durante as transmissões ao vivo

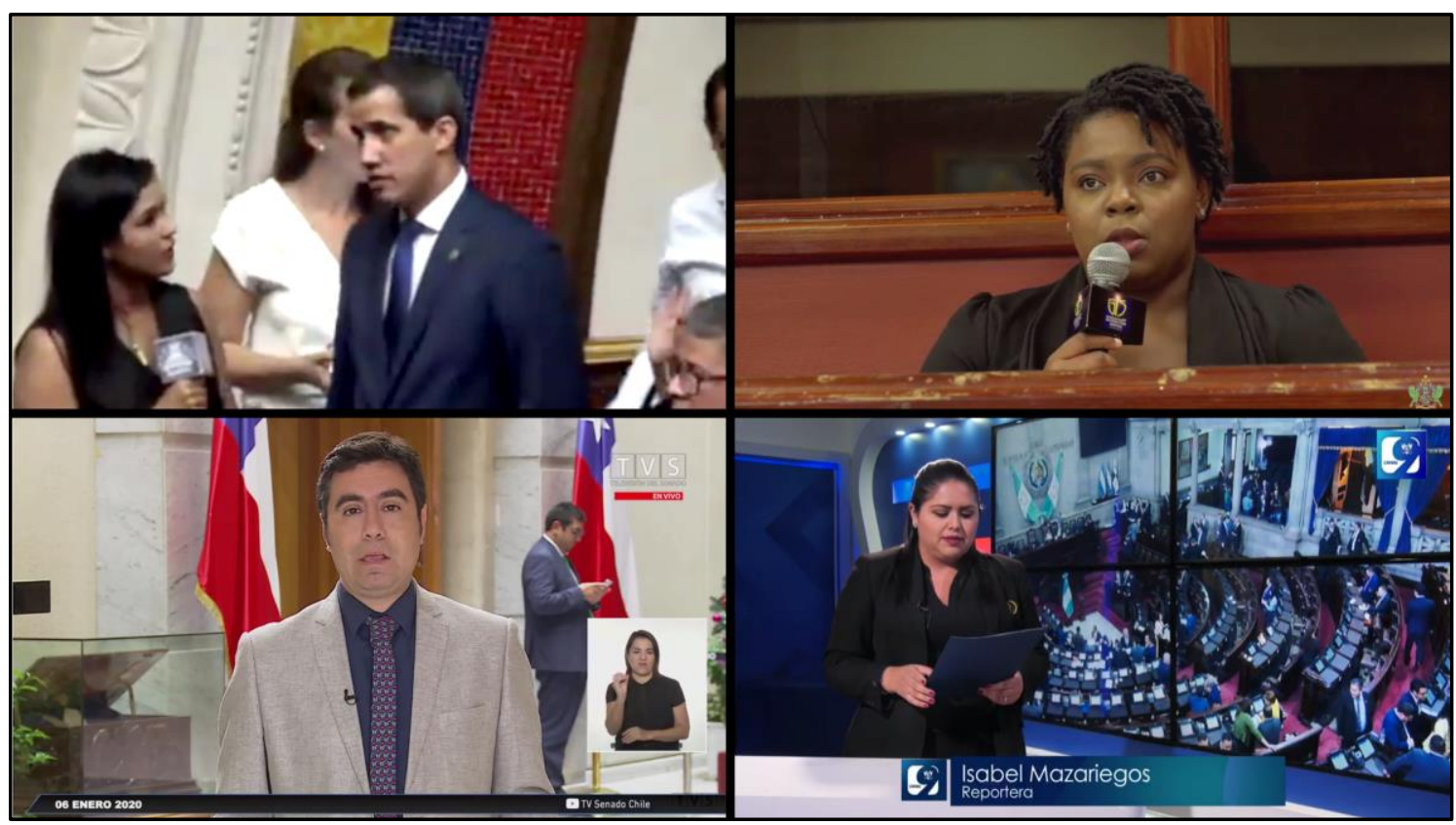

Fonte: Montagem feita a partir de frames captados pelas autoras (2020). Acima, à esquerda (Venezuela), em 30/10/20 de https://youtu.be/SouVgAcKMpE. Acima, à direita (Santa Lúcia), em 03/11/19 de https://youtu.be/39yE4Nw6SZ4. Abaixo, à esquerda (Chile), em 25/02/20 de https://youtu.be/fOjKt04iEJo. E abaixo, à direita (Guatemala), em 29/02/20 de https://youtu.be/URygOxOhEb0.

Sob o ponto de vista da localização do mediador, foi verificado que, das 23 casas parlamentares que se utilizam de jornalistas em vídeo para fazer explicações, 16 permitem que as entradas ao vivo se originem de dentro do plenário, seja no meio dos parlamentares (floor), seja nas galerias ou em espaços reservados para a imprensa. Nas demais, o jornalista ou entra ao vivo do lado de fora do plenário ou em estúdio. O detalhamento dos padrões encontrados está no Quadro 2 abaixo. 
Quadro 2 - Localização do jornalista/comunicador no momento da entrada ao vivo

\begin{tabular}{|c|c|}
\hline Localização do mediador & Casa legislativa \\
\hline \multirow{5}{*}{ No estúdio } & Bahamas - House of Assembly \\
\hline & Cuba - Asamblea Nacional del Poder Popular \\
\hline & Estados Unidos - Senate (sinal C-SPAN2) \\
\hline & Jamaica - House of Representatives \\
\hline & Jamaica - Senate \\
\hline Fora do plenário e no estúdio & Chile - Cámara de Diputadas y Diputados \\
\hline Fora do plenário & Chile - Senado \\
\hline Dentro e fora do plenário & Equador - Asamblea Nacional \\
\hline Dentro do plenário e no estúdio & Peru - Congreso \\
\hline \multirow{14}{*}{ Dentro do plenário } & Argentina - Senado \\
\hline & Brasil - Câmara dos Deputados \\
\hline & Colômbia - Cámara de Representantes \\
\hline & Costa Rica - Asamblea Legislativa \\
\hline & El Salvador - Asamblea Legislativa \\
\hline & Guatemala - Congreso \\
\hline & Honduras - Congreso Nacional \\
\hline & $\begin{array}{c}\text { México - Cámara de Diputados (sinal Canal } \\
\text { del Congreso) }\end{array}$ \\
\hline & México - Senado (sinal Canal del Congreso) \\
\hline & Nicarágua - Asamblea Nacional \\
\hline & Panamá - Asamblea Legislativa \\
\hline & Santa Lúcia - House of Assembly \\
\hline & Santa Lúcia - Senate \\
\hline & Venezuela - Asamblea Nacional \\
\hline
\end{tabular}

Fonte: Elaboração própria (2020). 
O que se observou é que há mais entrevistas com parlamentares nas transmissões em que as entradas ao vivo dos jornalistas se originam dentro do recinto do plenário e nas quais os profissionais têm liberdade de circular entre os legisladores e abordá-los. Isso não ocorre, por exemplo, na Guatemala ou em Santa Lúcia, onde o comunicador faz a intervenção ao vivo diretamente das galerias.

\subsubsection{Explicações orais}

Apenas oito (16\%) casas parlamentares inserem explicações faladas sobre a imagem do plenário, em formato de narração ou voiceover, sem que a figura do jornalista/comunicador apareça no vídeo. A importância dessas explicações se justifica pelos mesmos motivos que as intervenções jornalísticas em tela, descritas anteriormente: são informações de contexto, que traduzem o linguajar legislativo, narrando o fato de forma a estabelecer uma relação entre o texto técnico e o impacto do mesmo na realidade social.

As ocorrências das informações faladas variam conforme o momento da transmissão ao vivo em que tais informações em áudio são disponibilizadas. Os registros podem ser classificados da seguinte maneira:

- $\quad$ Antes da sessão: Cámara de Diputadas y Diputados do Chile;

- $\quad$ Antes e durante a sessão: House of Representatives e Senate dos Estados Unidos (sinal transmitido pela C-SPAN);

- Depois da sessão: Asamblea Legislativa da Costa Rica;

- $\quad$ Somente durante a sessão: Câmara dos Deputados do Brasil e Congreso do Peru;

- Durante e depois da sessão: Parlamentos unicamerais do Equador e Panamá.

A utilização de narração é limitada aos momentos em que os parlamentares não estão fazendo uso da palavra. Uma única exceção foi encontrada na Câmara dos Deputados brasileira, em que há voiceover em momentos específicos da sessão, notadamente de técnica legislativa, como na leitura da ata (na abertura de algumas sessões), na renovação de sessão (regimentalmente, uma sessão pode durar até cinco horas, após esse prazo precisa ser encerrada e iniciada uma nova, mesmo que seja com a mesma pauta) e no relato do trâmite da proposição (leitura obrigatória no início do processo de votação). Os jornalistas que participam da transmissão ao vivo fazem uso desses períodos para oferecer mais explicações sobre o conteúdo das propostas em deliberação, sobre os acordos parlamentares e até mesmo sobre situações externas ao plenário, mas que interferem diretamente no trabalho ali desenvolvido, como fatos que estão gerando repercussão nos discursos parlamentares ou proposições consideradas prioritárias, mas que ainda estão em análise em comissões específicas. 


\subsubsection{Mais de uma transmissão disponível ao cidadão}

Na maioria dos países analisados, a transmissão ao vivo de plenário oferecida pelo sinal televisivo é replicada na internet, possibilitando que o público on-line possa também acompanhar o evento legislativo. Mas em dois países foi verificada uma situação atípica, em que o responsável pelo broadcast e pelo webcast são distintos e independentes, e colocam coberturas diferenciadas à disposição do público. Nos Estados Unidos e no México, a população possui duas opções para assistir às sessões plenárias ao vivo: no site da própria casa legislativa, gerido pela própria instituição, ou no canal televisivo dedicado ao Parlamento, de responsabilidade de terceiros ${ }^{5}$. Nos Estados Unidos, a C-SPAN é completamente independente do Legislativo, podendo estabelecer regras e prioridades em relação ao que é veiculado. Já no caso do México, o Parlamento tem o controle porque o Canal del Congreso necessita seguir diretrizes ditadas por uma comissão bicameral, formada por deputados e senadores, sem a participação da sociedade.

O que merece destaque nesses dois países é que a responsabilidade diferenciada da transmissão implica também em conteúdo diversificado entregue ao cidadão. Em linhas gerais, a imagem e o som da sessão plenária são os mesmos, com captação controlada pelo Legislativo, porém há diferença na informação disponibilizada: a cobertura ao vivo das emissoras de TV agrega mais conteúdo.

No caso dos Estados Unidos, a transmissão feita pela webpage oficial de cada casa legislativa inclui apenas informações escritas, enquanto a veiculada pela C-SPAN insere mais dados em tela e também outros tipos de informação nos momentos em que há silêncio no plenário, como nas votações e nos intervalos entre discursos (no Senado estadunidense, períodos sem oradores são frequentes e podem atingir dezenas de minutos). Nessas oportunidades, a C-SPAN divide a tela, inclui trechos editados de momentos anteriores da sessão, entrevistas, explicações em formato de narração ou com o aparecimento de jornalista em estúdio e até inserções ao vivo de outros espaços do Congresso. Ou seja, nos Estados Unidos, o público pode escolher uma cobertura mais informativa e contextualizada (C-SPAN) ou simplesmente assistir a sessão plenária sem nenhum tipo de intervenção, somente com dados escritos em tela que indicam o projeto em votação, o nome e partido do orador, o chamamento de quórum e o resultado da votação (os webcastings da House of Representatives e do Senate estão inseridos em sites que agregam dados técnicos sobre o processo legislativo, em linguagem formal). A Figura 3 exemplifica como é evidente a diferença informativa entre as transmissões ao vivo realizadas pelo site oficial (acima) e pela C-SPAN (abaixo).

\footnotetext{
${ }^{5}$ No Canadá, também há fontes diferenciadas de transmissão ao vivo das sessões plenárias - um canal televisivo privado (CPAC) e o webcast do site da House of Commons e do Senate, mas o conteúdo que chega ao público por meio de ambas fontes é o mesmo, por isso não se enquadra neste ponto de análise.
} 
Figura 3 - Comparativo entre a transmissão ao vivo do plenário do Senate dos Estados Unidos via site oficial e via C-SPAN2

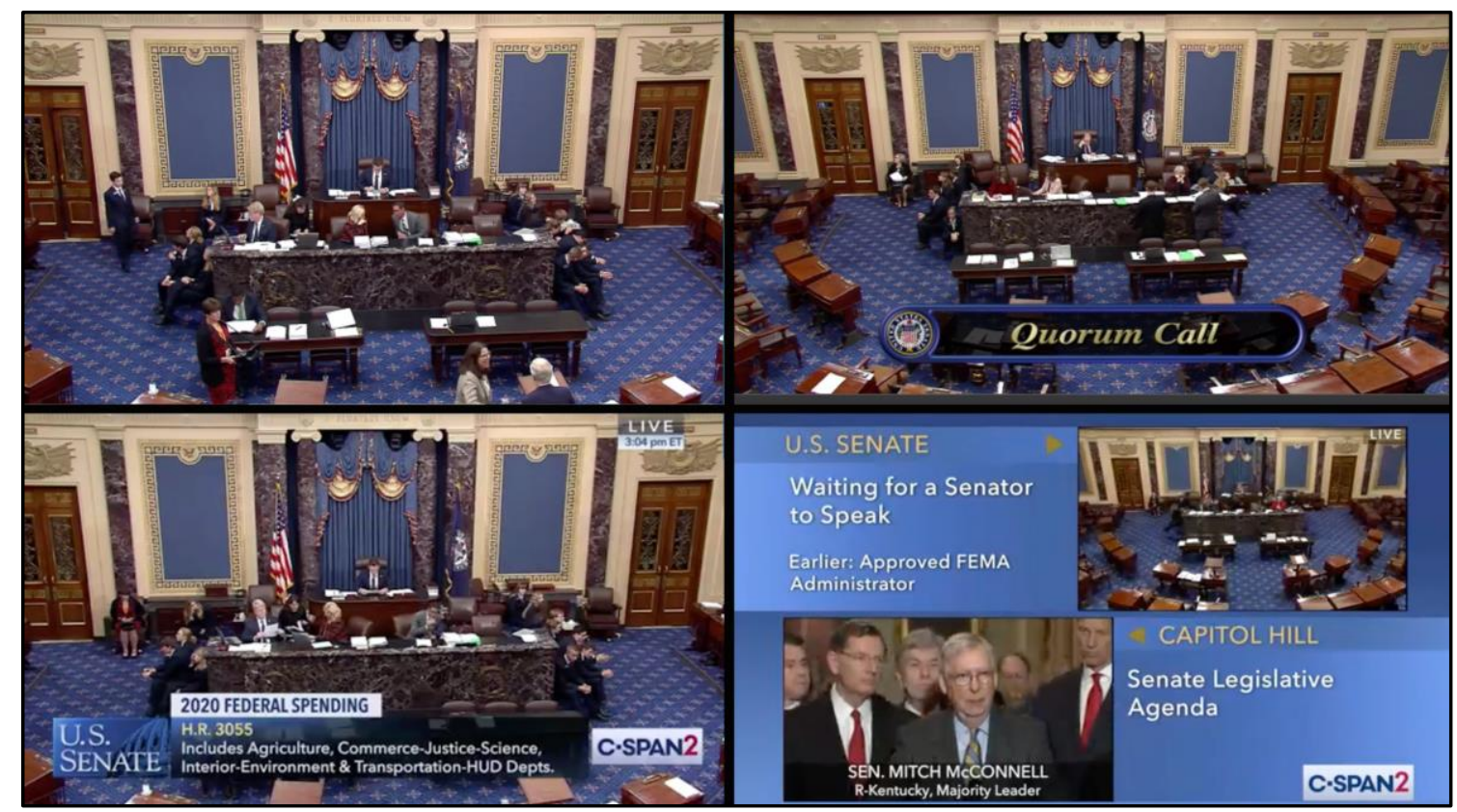

Fonte: Frames captados pelas autoras (2020). À direita, de 28/02/20, acima de https://floor.senate.gov/MediaPlayer.php?view_id=2\&clip_id=3606 e abaixo, de https://www.cspan.org/video/?465752-1/senate-session. À esquerda, de 14/01/20, acima de https://floor.senate.gov/MediaPlayer.php?view_id=2\&clip_id=3544 e abaixo de https://www.cspan.org/video/?468109-2/senate-session-part-2.

O que ocorre no México é similar. Somente a transmissão do Canal del Congreso (tanto em broadcast quanto na internet) inclui mediação jornalística falada e em vídeo - que é feita por meio de um repórter dentro do plenário. E há diferença de padrão entre Cámara de Diputados e Senado. O webcast da Cámara de Diputados não usa exatamente o mesmo sinal de vídeo do Canal del Congreso - nos momentos em que não há parlamentares falando, é colocada uma imagem geral do plenário e o áudio ambiente; enquanto a transmissão equivalente do Canal del Congreso insere a imagem e o áudio de um jornalista fazendo explicações sobre o que está ocorrendo na sessão. As informações escritas do webcast são mais burocráticas e menos explicativas que as do Canal del Congreso.

No Senado mexicano, o webcast usa exatamente o mesmo sinal de vídeo, mas não o de áudio, o que gera uma situação estranha para quem está assistindo: quando há ausência de oradores, aparece um jornalista em tela para fazer explicações, mas o áudio do profissional vai ao ar apenas no Canal del Congreso - no webcast, aparece a imagem dele sem som. Quem assiste a sessão pelo canal do Senado no YouTube não compreende o porquê disso e reclama no chat da falta de áudio do repórter. A resposta é que o sinal não está disponível. Outro diferencial é que o streaming do próprio Senado não agrega nenhuma informação, nem ao menos escrita, para identificar legisladores ou o projeto em votação - ao contrário do que vai ao ar no Canal del Congreso, que agrega explicações escritas, faladas e de jornalista em vídeo, como já referido 
anteriormente.

O que se depreende da comparação entre as transmissões oferecidas no México é que apesar da disponibilidade de sinais diferenciados à população, é a veiculada pelo Canal del Congreso a mais abrangente do ponto de vista informativo, já que se utiliza da oralidade e de linguagem simples para explicar as pautas e o contexto político em tempo real.

\subsection{Perfil das casas parlamentares conforme nível informativo das transmissões}

Esta etapa da pesquisa tem o intuito de traçar um perfil das casas parlamentares agrupadas conforme o acréscimo (ou não) de informação frente ao registro puro de áudio e vídeo das sessões plenárias transmitidas ao vivo. Tais conjuntos de legislativos foram analisados sob a ótica de mais de 50 critérios - aproximadamente 20 relacionados a aspectos políticos, sociais, econômicos e geográficos. Aqui serão apresentados apenas os resultados considerados relevantes.

Das 50 casas parlamentares que tiveram sessões analisadas, dez (20\%) não disponibilizam nenhum tipo de informação adicional à transmissão ao vivo - nem informações escritas, nem faladas, nem explicações dadas por jornalista aparecendo na tela. São parlamentos que tomaram a iniciativa da transparência, ao disponibilizar informação (RIVERA, 2008), neste caso, permitindo que os olhos do público vejam os atos de plenário em tempo real. No entanto, não deram o passo seguinte, o de implementar ações para o entendimento e envolvimento do público (CURTIN; MEIJER, 2006), ou seja, sem atitudes de publicidade e estímulo à accountability nas transmissões ao vivo, mantêm, de certa forma, a assimetria informacional entre principal (povo) e agent (representante) (FILGUEIRAS, 2011).

Os legislativos americanos que transmitem apenas o sinal bruto de áudio e vídeo da sessão plenária, sem adicionar dado algum, são:

- $\quad$ House of Representatives e Senate de Antígua e Barbuda;

- $\quad$ Cámara de Diputados e Cámara de Senadores da Bolívia;

- $\quad$ House of Assembly de Dominica;

- $\quad$ House of Representatives e Senate de Granada;

- $\quad$ Senado da República Dominicana;

- $\quad$ National Assembly de São Cristóvão e Neves;

- De Nationale Assemblée do Suriname.

São 40 as casas parlamentares do continente americano que oferecem algum tipo de informação adicional na transmissão ao vivo das sessões plenárias - acrescentando informações escritas, faladas e/ou permitindo a presença de jornalista na tela em algum momento da cobertura em vídeo. Este é um grupo bastante heterogêneo porque engloba desde os legislativos que apenas informam o nome do orador até os que fornecem explicações em tempo real sobre os impactos das propostas em disputa na sessão plenária. 
Entende-se que, neste grupo, os legislativos deram um passo na escala informativa das transmissões plenárias porque, ao menos, situam o público sobre quem é o parlamentar que está com a palavra - nome, cargo, de onde vem e qual partido pertence, por exemplo. Essas casas legislativas adicionam dados à transmissão ao vivo que aumentam o grau de transparência, mesmo que ainda não se atinja uma transparência clara (FOX, 2008). Da mesma forma, possuem elementos de publicidade e de incentivo à accountability, mesmo que incipientes e comprometidos pelo uso de linguagem técnica, o que prejudica a associação automática entre o que está em debate na arena política com a realidade social.

Estreitando ainda mais a análise, chega-se ao número de 24 casas legislativas que se utilizam da presença de jornalistas para adicionar informações orais - com ou sem a presença em vídeo - às transmissões ao vivo das sessões plenárias. Este grupo avança mais um degrau na escala informativa por utilizar profissionais que, além de entrevistarem os atores envolvidos nas decisões políticas ali realizadas, resumem e "traduzem" os procedimentos legislativos e as propostas que tramitam nas sessões plenárias para a linguagem popular. Esses jornalistas e comunicadores possuem conhecimento especializado, selecionam as informações e disponibilizam "à população o que ela PRECISA saber, para ter subsídios (informação clara, imparcial e plural), para o exercício da cidadania plena" (FREITAS, 2020, p. 16, grifo do autor). Como já vimos anteriormente, tais intervenções a favor do entendimento público, na maior parte das vezes, ocorrem antes e/ou depois do período protocolar da sessão plenária.

Os legislativos que veiculam explicações faladas - com ou sem o jornalista em vídeo durante o período regimental da sessão plenária são apenas oito:

- C Câmara dos Deputados do Brasil;

- $\quad$ Asamblea Nacional do Equador;

- $\quad$ House of Representatives e Senate dos Estados Unidos (sinal transmitido pela C-SPAN e C-SPAN2);

- $\quad$ Cámara de Diputados e Senado do México (sinal transmitido pelo Canal del Congreso); - $\quad$ Asamblea Nacional do Panamá;

- $\quad$ Congreso do Peru.

Considera-se este grupo de oito casas parlamentares no mais alto grau de nível informativo porque se utiliza de jornalistas para oferecer explicações ao longo da sessão. É uma intervenção que contribui mais acentuadamente para a publicidade dos debates e decisões parlamentares por produzir "informação verdadeira" (FILGUEIRAS, 2011, p. 79), inteligível, com vistas ao interesse público, na tentativa de oferecer uma imediata compreensão adequada dos fatos ou do resultado dos mesmos (GOMES; AMORIM; ALMADA, 2018) no momento em que ocorrem - e não apenas antes (uma expectativa do fato) ou depois (a concretização do fato).

A análise dos dados coletados na fase de observação sistemática direta mostra que alguns 
marcadores políticos, econômicos e geográficos variam progressivamente conforme o grau das informações inseridas na transmissão ao vivo das sessões plenárias, ou seja, certas características ficam mais acentuadas (ou reduzidas) quanto maior for o grau informativo. Para tanto, considerase, em síntese:

Grupo com primeiro nível informativo: composto pelas dez casas parlamentares que não adicionam nenhuma informação ao áudio e vídeo brutos da sessão;

Grupo com segundo nível informativo: formado pelas 40 casas legislativas que oferecem algum tipo de informação, mesmo que mínima, seja ela escrita ou oral;

- Grupo com terceiro nível informativo: composto pelas 24 casas parlamentares que se utilizam de mediação jornalística para veicular explicações faladas em algum momento da sessão plenária - e, como já vimos, tal intervenção se concentra no antes e/ou após o período regimental do evento parlamentar;

Grupo com quarto nível informativo: formado pelas oito casas legislativas que oferecem explicações orais - com ou sem a imagem do jornalista em tela - não somente antes ou após, mas também durante o período oficial da sessão plenária.

É possível verificar no Gráfico 8 que conforme se avança no grau informativo, maior a proporção de países mais populosos e presidencialistas. Também há maior percentual de parlamentos com membros eleitos por meio de sistema proporcional de votação, sujeitos à lei de liberdade de informação, com maior transparência ${ }^{6}$, independentes administrativamente do governo, compostos por mais de 100 membros e com mais de dez comissões permanentes.

\footnotetext{
${ }^{6}$ Como parâmetro de transparência foi utilizado o Índice Latinoamericano de Transparência Legislativa (ILTL). Embora limitado, é o único voltado exclusivamente para tal critério. Desenvolvido pela Rede Latinoamericana pela Transparência Legislativa (RLTL), que reúne 24 organizações civis de 13 países da região, o índice varia de 0 (pior avaliação) a 100 (melhor avaliação) e considera quatro dimensões relacionadas à transparência e responsabilidade dos parlamentos, como existência de normas e participação cidadã. Os dados adotados por esta pesquisa são do relatório de 2018.
} 
Gráfico 8 - Variação percentual de critérios políticos e legislativos conforme nível informativo das transmissões ao vivo das sessões plenárias

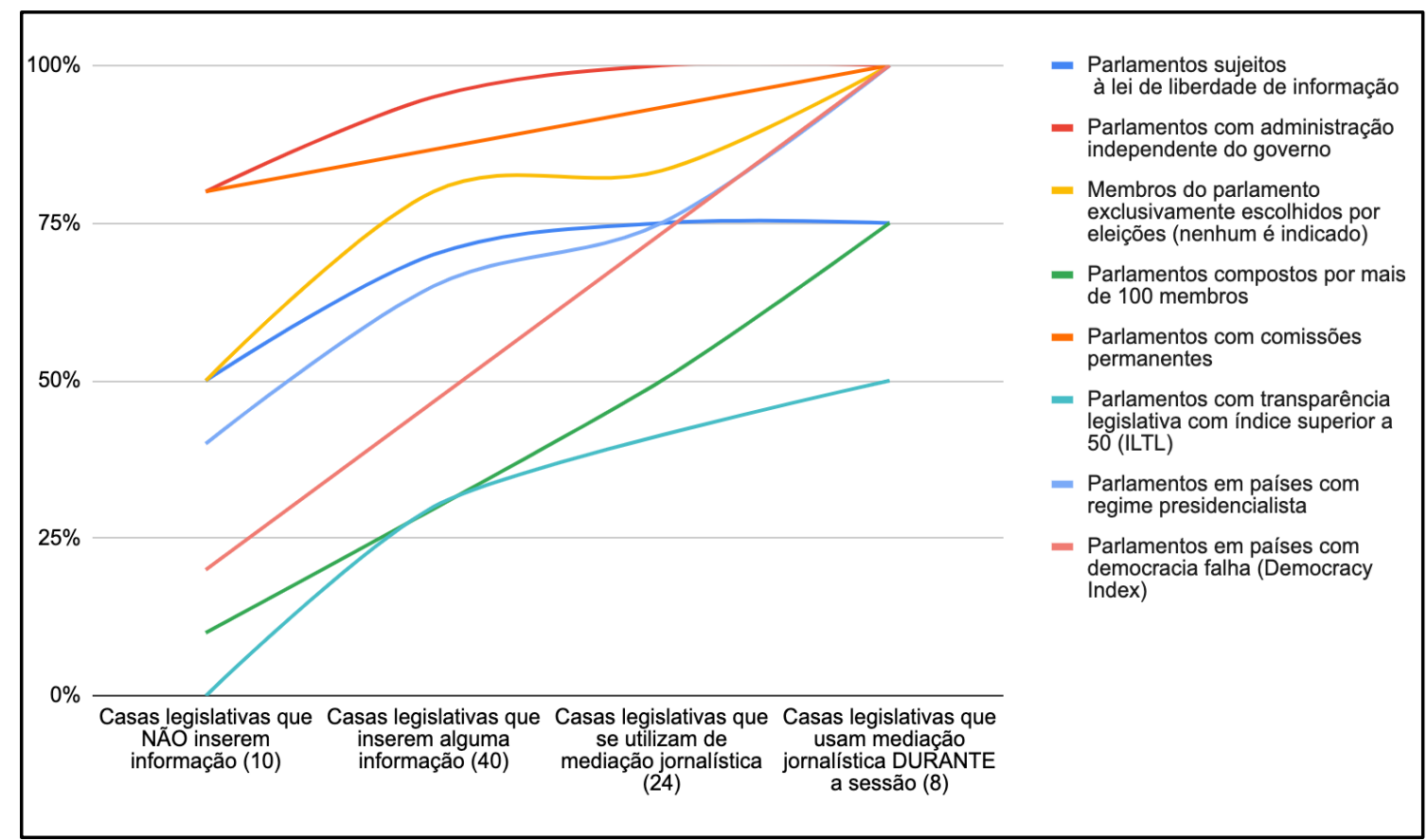

Fonte: Elaboração própria (2020).

Também foi verificado que algumas características geográficas, econômicas e sociais são mais acentuadas conforme se aumenta o grau informativo, como é possível observar no Gráfico 9 abaixo. No aspecto econômico, há redução do percentual de casas legislativas no grupo de países com PIB per capita mediano (entre US\$10 mil e US\$20 mil) - há uma migração para os grupos que registram PIB per capita acima de US\$20 mil e abaixo de US\$10 mil, sendo que este último é o que concentra mais parlamentos $(62,5 \%)$ quando se alcança o nível máximo de inserção de informações durante as transmissões ao vivo.

Quanto à desigualdade de renda, verifica-se quanto maior o grau de informação nas transmissões plenárias ao vivo, maior a proporção de casas legislativas localizadas em países cujo Índice de Gini $^{7}$ registra o nível mais baixo de desigualdade de renda. O grupo com maior nível informativo é formado por casas legislativas de países com alguma desigualdade de renda - ou no primeiro nível $(87,5 \%)$ ou acima $(12,5 \%)$.

No aspecto geográfico, constata-se que quanto maior o grau informativo, maior o percentual de países localizados na América do Norte e menor os que ficam nas Antilhas. A relação decrescente também é verificada quando se trata de tamanho territorial: a proporção de legislativos de países pequenos, com área de até 200 mil km² (equivalente ao Estado do Paraná), é menor no grupo que oferece mais informação legislativa nas transmissões.

\footnotetext{
${ }^{7}$ Para classificação, o Índice de Gini considera que até 0,399 o país possui igualdade; a partir de 0,4 , há desigualdade de renda - a primeira faixa, de 0,4 a 0,499 é a de nível mais ameno. Quanto mais próximo o número de 1, maior a desigualdade.
} 
Gráfico 9 - Dados sobre critérios geográficos, econômicos e sociais que variaram conforme ampliação do nível informativo das transmissões plenárias ao vivo

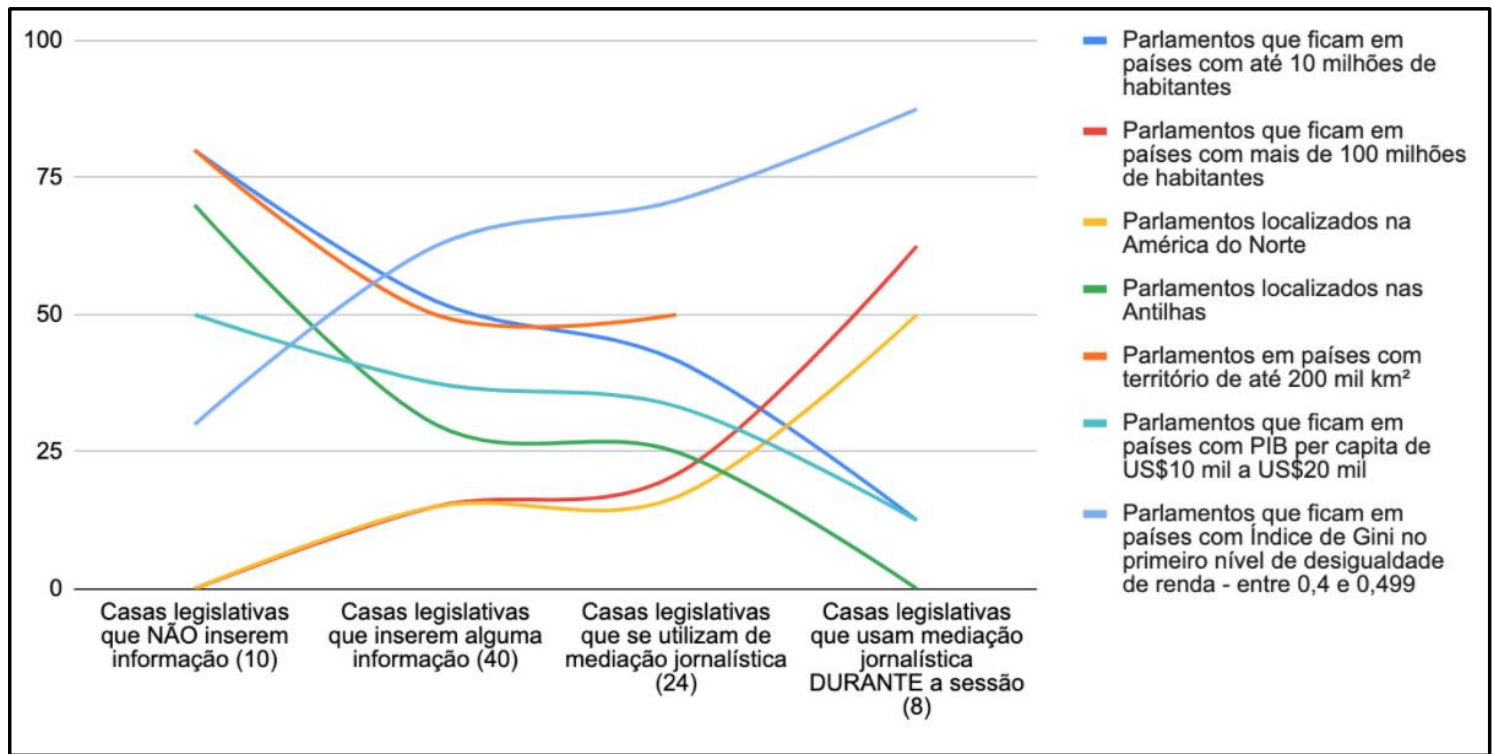

Fonte: Elaboração própria (2020).

Outros critérios analisados por esta pesquisa não mostraram uma variação diretamente relacionada ao aspecto informacional das transmissões ao vivo, tais como quem decide quando há impasse entre Executivo e Legislativo sobre propostas legislativas, IDH e classificação de regimes pelo Democracy Index, exceto a de democracia falha, exposto no Gráfico 8 já apresentado, que apresentou variação crescente conforme o maior nível informativo das transmissões.

A sistematização e análise dos dados também possibilitou verificar que quanto mais informações fornecidas na transmissão ao vivo, maior também a divulgação das atividades de plenário como um todo, em outros formatos. Os percentuais dispostos no Gráfico 10 levam a inferir que as sessões divulgadas em tempo real com mais explicações se inserem em uma estratégia deliberada das instituições em dar amplo conhecimento ao público dos feitos legislativos, não se limitando apenas à divulgação ao vivo e registro da sessão plenária em vídeo. 
Gráfico 10 - Dados sobre meios e ações de divulgação das sessões plenárias que variaram conforme ampliação do nível informativo das transmissões

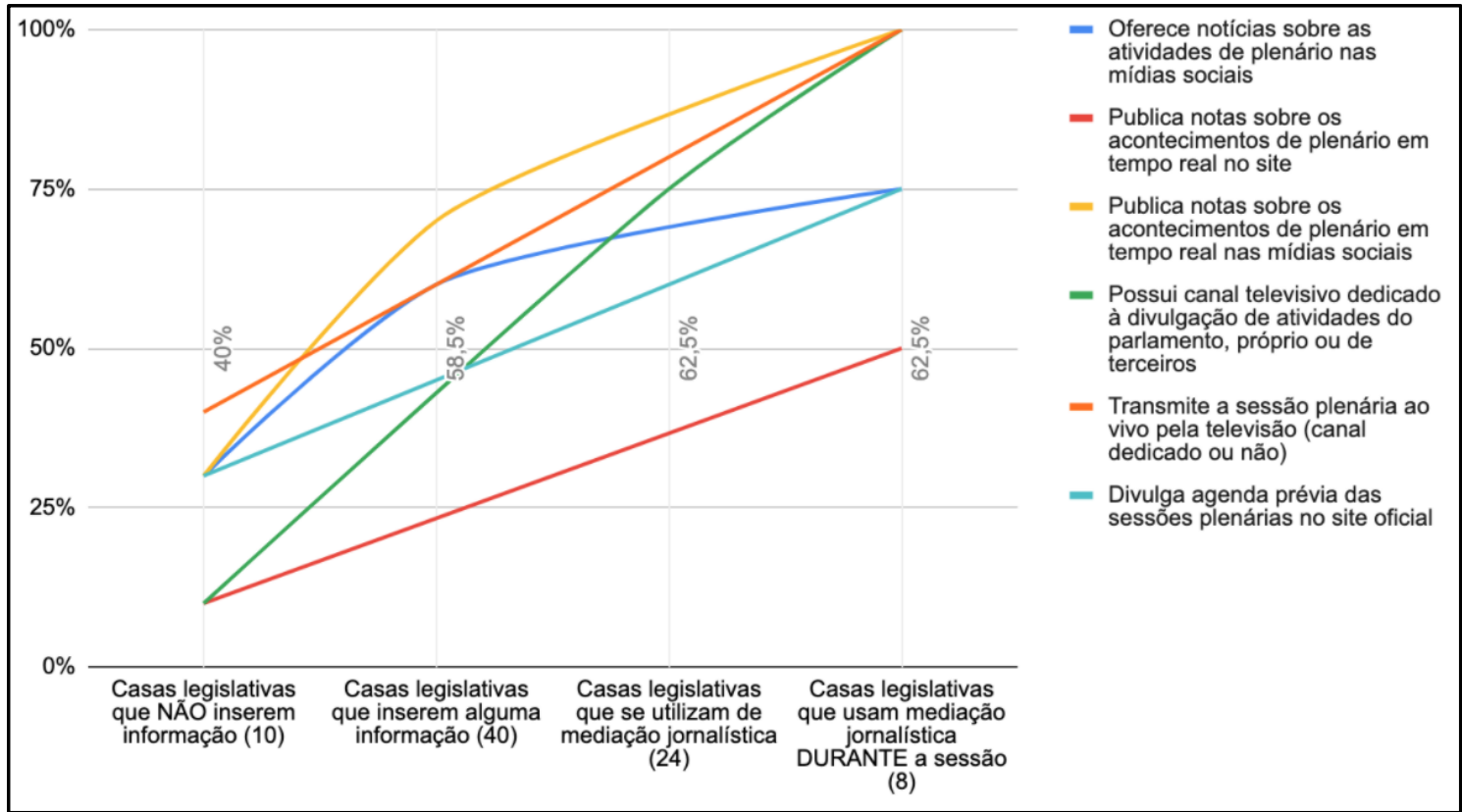

Fonte: Elaboração própria (2020).

Outra constatação é que quanto quanto maior o grau informacional das transmissões ao vivo das sessões plenárias, maior o percentual de casas legislativas que valorizam o site oficial como local de referência na internet para tal streaming e para o armazenamento das gravações em vídeo das sessões - por consequência, menor é o percentual de casas parlamentares que se utilizam de plataformas de vídeo privadas como repositórios. A variação pode ser observada no Gráfico 11 a seguir:

Gráfico 11 - Dados sobre streaming e armazenamento das sessões plenárias na internet que variaram conforme ampliação do nível informativo das transmissões ao vivo

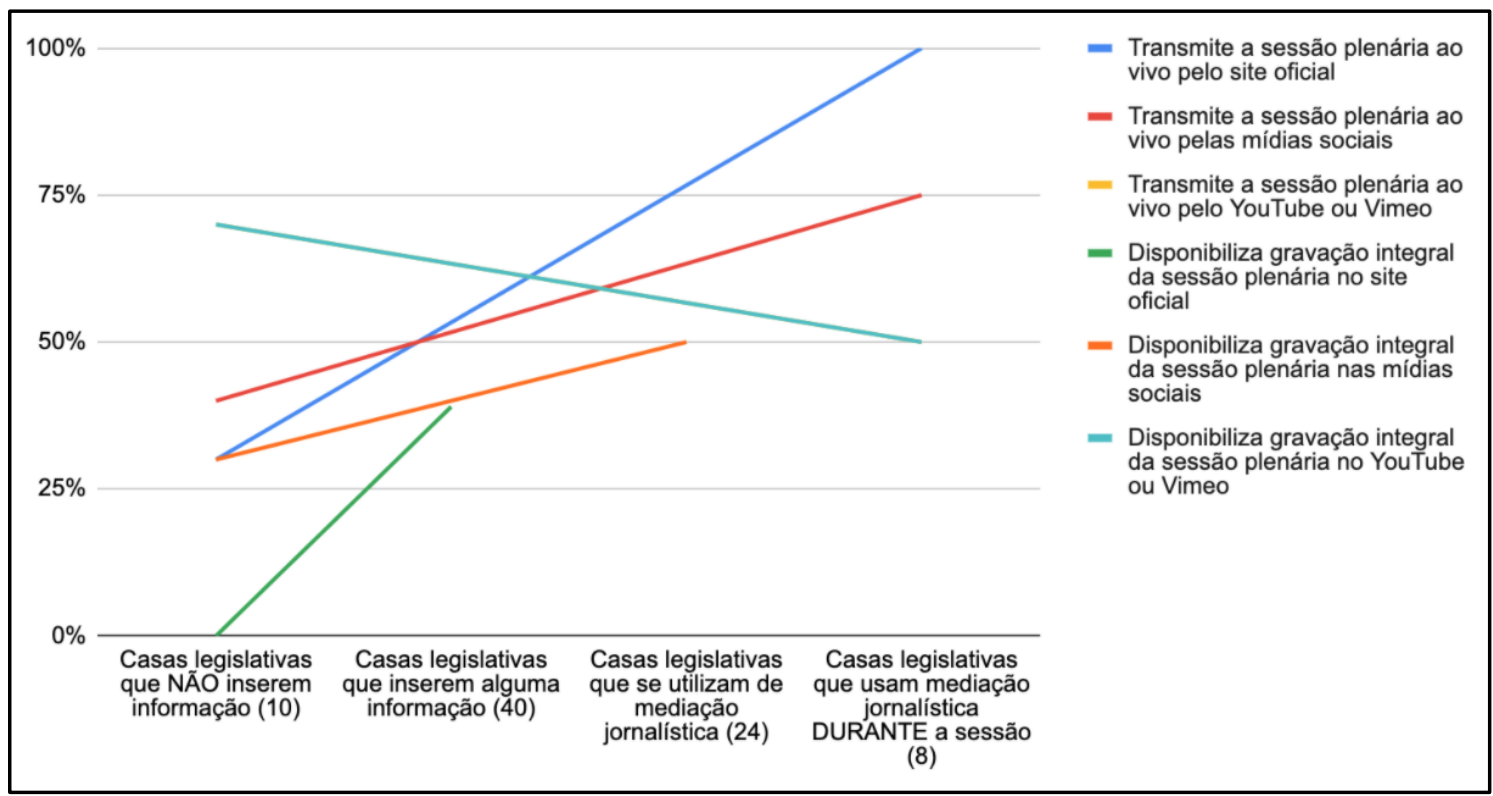

Fonte: Elaboração própria (2020). 
Cabe fazer a ressalva de que os critérios que tratam da disponibilização de agenda prévia das sessões no site e oferecimento de transmissão ao vivo e de gravação integral em vídeo da sessão plenária pelo site não possuem uma variação completamente crescente - é verificada uma alteração na tendência em meio à intensificação do grau informativo das transmissões. No entanto, entende-se que tal desvio não é impeditivo para afirmar que existe uma agudização dos percentuais nas variáveis, principalmente porque tal movimento é constatado ao se analisar o comportamento geral dos grupos informativos em cada quesito.

\section{Conclusão}

O presente mapeamento mostra que, entre as casas parlamentares do continente americano, existem graus diferenciados de transparência, publicidade e estímulo à accountability nas transmissões ao vivo das sessões plenárias, variando conforme o conteúdo que é disponibilizado ao cidadão.

De modo geral, os legislativos americanos se inserem na tendência de utilizar transmissão ao vivo em vídeo das sessões plenárias como instrumento de transparência (INTERPARLIAMENTARY UNION, 2018). Com isso, pretendem alcançar visibilidade (CANADA, 2016), legitimidade (LEÓN, 2012), maior engajamento (GRIFFITH; LESTON-BANDEIRA, 2012), além de potencialmente incentivar a accountability, pois ao debater em público, estão sujeitos a ser responsabilizados pelo público (HAJER, 2009). Ao viabilizarem a transmissão ao vivo das sessões plenárias, os parlamentos possibilitam que a sociedade vivencie a autenticidade dos acontecimentos no momento em que estão ocorrendo (CARLÓN, 2012) e verifiquem como os legisladores estão agindo de fato, mesmo estando longe fisicamente (MEYROWITZ, 1985; CRAIN; GOFF, 1988; MARRIOTT, 2007).

Por dar visibilidade ao evento parlamentar, a transmissão ao vivo em vídeo é uma ferramenta efetiva de transparência, embora limitada pelos parlamentos em termos do que pode ser visto. Verifica-se que existem desde iniciativas com transparência opaca (FOX, 2008), em que o cidadão não consegue sequer saber o nome do deputado ou senador que está ao microfone, até iniciativas com grau de transparência clara (FOX, 2008), em que há visibilidade das informações que permitem conclusões precisas a partir delas (MICHENER; BERSCH, 2013).

Constatou-se ainda que, quanto maior o grau informativo das transmissões plenárias, maior é também a divulgação das ações de plenário por outros meios e formatos, como divulgação de agenda prévia e de notícias no site oficial ou nas mídias sociais. Entende-se que esse cenário mostra um compromisso dessas casas legislativas com a compreensão adequada dos fatos, com a publicidade, que é marcador indispensável de qualidade democrática (GOMES; AMORIM; ALMADA, 2018).

Considerando que transparência e publicidade são basilares para a accountability, é possível afirmar que a mesma é potencializada conforme o maior grau informativo das 
transmissões ao vivo das sessões plenárias, por permitirem não somente acesso ao conteúdo, mas inteligibilidade, que aumenta a capacidade dos representados cobrarem seus representantes (SANTOS, 2003; LEMOS; BARROS; BERNARDES, 2017). Ao promover compreensão, a transmissão ao vivo ainda se apresenta como instrumento para uma conexão contínua entre representantes e representados (BARRETO, 2018). Também neste quesito conclui-se que há níveis diferenciados nos legislativos do continente. Quanto maior é o grau informativo da transmissão ao vivo, maior o estímulo à accountability parlamentar.

As transmissões ao vivo em vídeo das sessões plenárias ainda colaboram para efetivar o direito de acesso à informação; auxiliam para o letramento político quando fazem uso de linguagem simples para proporcionar compreensão frente a um público amplo e heterogêneo; propiciam uma sociedade mais informada (LEÓN, 2012); e auxiliam na busca por maior engajamento público (LESTON-BANDEIRA, 2014). Tais vertentes também são mais favorecidas quanto mais dados e explicações em tempo real são oferecidas ao público.

A análise pormenorizada das informações orais oferecidas ao longo da transmissão ao vivo das sessões plenárias mostra padrões que apontam para a mínima interferência de profissionais de comunicação. Há uma preocupação em não violar o espaço simbólico dos legisladores - no espaço e tempo da sessão plenária, podem ter acesso à palavra apenas representantes eleitos ou pessoas por eles autorizadas. Mesmo ao transmitir o evento por meios de comunicação, a liturgia é mantida, preserva os parâmetros de processo legislativo em vez de adotar técnicas midiáticas, caracterizando o que Barreto (2018) chamou de parlamentarização da mídia. Isso justifica porque as entradas ao vivo de repórteres e locutores se concentram no antes e/ou depois do período regimental das sessões. E mesmo quando há explicações em tempo real durante o período oficial do evento, são realizadas apenas nos intervalos entre os discursos parlamentares, de forma a não comprometer a fala de quem foi legitimamente delegado pelo povo. Verifica-se um paradoxo: a transmissão ao vivo das sessões plenárias é feita para os cidadãos, um público difuso, que é em parte desinteressado e carente de letramento político; no entanto, precisa veicular os fatos segundo as regras regimentais do evento em si, que geralmente são desconhecidas desse mesmo público.

A pesquisa se debruçou sobre a análise de aspectos técnicos da transmissão, pois têm o poder de limitar a transparência, ao determinar o que será visto pelo público, como e quando (GOMES; AMORIM; ALMADA, 2018), o que pode ter implicações diretas na publicidade e no estímulo à accountability. Foram verificados cinco padrões de variação de planos, que permitem, em maior ou menor grau, ter noção da sessão plenária como um todo. O mais encontrado, utilizado por quase metade das casas legislativas que tiveram as sessões analisadas, é o que insere a imagem do plenário inteiro apenas nos momentos de votação e na troca de oradores. Apenas $34 \%$ das casas legislativas possibilitam verificar reações de pares ou do plenário todo durante uma fala parlamentar. Dezesseis por cento não mostram o plenário completo em nenhum momento da 
transmissão. Essas constatações confirmam que também no âmbito do continente americano existe o uso de imagens controladas, assim como apontado por Renault (2004) e Barreto (2018) em estudos sobre o Brasil. As casas legislativas controlam a captação de áudio e vídeo e, na maioria das vezes, não permitem contextualização visual de um discurso.

A internet é o meio em que mais se difundem as sessões plenárias ao vivo e vem servindo de ambiente para repositório das gravações das sessões, que ficam disponíveis para acesso quando o cidadão desejar (embora nem sempre sejam fáceis de encontrar, por falta de organização dos conteúdos). É importante notar que em um contexto de midiatização, em que está presente uma intensa interação comunicacional que articula diversos dispositivos tecnológicos (VERÓN, 2014), com relações cada vez mais intermediadas por veículos de comunicação e articuladas entre sociedade e banco de dados virtuais (BRAGA, 2015), a presença na internet das sessões plenárias ao vivo expande o alcance desses eventos, fornecendo informações a mais cidadãos, de modo a ampliar a arena de julgamento político para além das eleições, criando um movimento circular de opiniões entre instituições de Estado e sociedade (URBINATI, 2013). O maior alcance dos pronunciamentos também potencializa as oportunidades de constituição da representação ao longo do mandato (BARRETO, 2018), já que a comunicação personifica simbolicamente a figura do parlamentar (COLEMAN, 2005). Ainda contribui para accountability, pois estimula o acompanhamento e a fiscalização dos atos legislativos, a responsividade e a prestação de contas, a melhora da qualidade dos debates (SANTOS, 2008), o engajamento público (LESTONBANDEIRA, 2014) e a geração de uma opinião pública mais informada (LEÓN, 2012).

A diversificação da oferta de transmissões ao vivo pela internet vai ao encontro da popularização do uso da web. Nos últimos 15 anos, o número de usuários vem crescendo $10 \%$ ao ano - 77,2\% da população do continente americano são usuários de internet (ITU, 2019). No entanto, não pode ser ignorado que há um problema de penetração da tecnologia. Dados da União Internacional de Telecomunicações (2019) mostram que apesar de 96,6\% do território americano ser coberto por sinal de internet, existe uma considerável exclusão digital, que varia conforme o país, mas, na maioria deles, se encontra entre $25 \%$ e $50 \%$ da população. Isso tem impacto especialmente junto à população mais pobre, que quando tem acesso à internet, o mesmo é limitado em termos de velocidade e volume de dados, o que pode inviabilizar o acesso a transmissões ao vivo em vídeo. Ou seja, o investimento dos parlamentos em webcasts pode ser considerado um avanço, mas as instituições públicas como os parlamentos não podem ignorar que o ambiente virtual ainda é desigual.

Se, por um lado, os legislativos estão aproveitando a oportunidade de barateamento e popularização das tecnologias para informar em tempo real a sociedade sobre os atos de plenário, de outro, surge uma preocupação quanto à autonomia das instituições sobre o conteúdo: entre os parlamentos americanos, o YouTube é a principal plataforma de transmissão ao vivo e o repositório mais usual de gravações na íntegra de sessões plenária (recurso utilizado por $63,6 \%$ 
das casas parlamentares). As mídias sociais Facebook e Twitter também possuem relevância neste cenário (43,6\% transmitem ao vivo, $40 \%$ utilizam como local de armazenamento para gravações de sessões). São situações em que dados públicos ficam sujeitos a decisões privadas e comerciais que visam o lucro.

Mais um ponto que merece destaque é que apenas dar visibilidade à sessão parlamentar não é suficiente, porque a falta de entendimento do que ocorre no evento legislativo compromete a transparência clara (FOX, 2008), a publicidade e a accountability, especialmente a vertical, que ocorre na relação entre a sociedade e as instituições públicas (SCHEDLER, 2004). Por isso, a pesquisa estabeleceu quatro níveis informativos utilizados nas transmissões das sessões plenárias, partindo do grupo que não adiciona nenhum dado ao registro bruto de imagens e sons; passando pelo grupo que insere alguma informação, mesmo que mínima, como apenas a identificação do orador; o grupo de casas legislativas que se utilizam da mediação jornalística para fazer as explicações, principalmente antes e após o período regimental da sessão; chegando ao último nível, que consiste no grupo de parlamentos que inserem explicações feitas por jornalistas ao longo de toda a transmissão, inclusive durante o período oficial do evento. Podemos avaliar que essa é uma ação direcionada ao fortalecimento da representação, pois diminui a desinformação do público frente à atuação dos parlamentares (BARROS; BERNARDES; RODRIGUES, 2014).

Como desafio, identifica-se a necessidade de os parlamentos do continente americano qualificarem as informações fornecidas durante a transmissão ao vivo em vídeo das sessões plenárias, de forma a oferecer uma transparência clara ao cidadão. Também necessitam ampliar as iniciativas de publicidade para proporcionar maior entendimento, com informações que permitam a conexão dos atos legislativos com a vida cotidiana da população - isso porque as explicações em linguagem clara e em tempo real da sessão ainda são restritas a um grupo pequeno de casas legislativas. É a compreensão que torna a informação útil e a transforma em ferramenta para a busca de outros direitos. É entendendo o impacto e a importância das decisões parlamentares que a população poderá compreender melhor a relevância do Legislativo em si para o sistema democrático e para a sociedade. A liturgia legislativa é importante, mas a transmissão ao vivo em vídeo pretende agradar aos cidadãos ou aos parlamentares? Ainda é preciso que os parlamentos se apropriem das tecnologias para criar ações efetivas de engajamento público (LESTON-BANDEIRA, 2014) - e uma maior interatividade na internet pode ser uma delas -, propiciando que os cidadãos se aproximem da instituição e participem da construção de políticas públicas voltadas ao interesse comum. 


\section{Referências}

AGORA. Portal for Parliamentary Development. 2019. Disponível em: https://agoraparl.org/resources/aoe/transparency-in-parliament. Acesso em: 14 nov. 2019.

BARRETO, Rachel Cardoso. Tribuna ao vivo: discussão, representação e os avessos suscitados pela midiatização do parlamento. 2018. 295 f. Tese (Doutorado em Ciência Política) - Faculdade de Filosofia e Ciências Humanas, Universidade Federal de Minas Gerais, 2018.

BARROS, Antônio Teixeira; BERNARDES, Cristiane Brum; RODRIGUES, Malena Rehbein. O discurso fundador das mídias legislativas da câmara dos deputados. E-Legis - Revista

Eletrônica do Programa de Pós-Graduação da Câmara dos Deputados, Brasília, v.7, n. 14, p. 7-25, maio/ago. 2014. Disponível em: http://e-legis.camara.leg.br/cefor/index.php/elegis/article/view/184. Acesso em: 17 nov. 2019.

BEETHAM, David. Parliament and democracy in the twenty-first century: A guide to good practice. Geneva: Inter-parliamentary Union, 2006. E-book. Disponível em:

http://archive.ipu.org/PDF/publications/democracy_en.pdf. Acesso em: 14 nov. 2019.

BERNARDES, Cristiane Brum. Parlamentares $\times$ jornalistas: a dinâmica política das mídias legislativas da Câmara dos Deputados. Revista Sociedade e Estado, Brasília, v. 28, n. 3, p. 663-689, set./dez. 2013b. Disponível em: https://www.scielo.br/pdf/se/v28n3/a11v28n3.pdf.

Acesso em: 28 jul. 2020.

BRAGA, José Luiz. Lógicas da mídia, lógicas da midiatização? In.: FAUSTO NETO, Antonio; ANSELMINO, Natalia Raimondo; GINDIN, Irene Lis (ed.). Relatos de investigaciones sobre mediatizaciones. Rosario: UNR Editora. 2015, p. 15-32. E-book. Disponível em: https://rephip.unr.edu.ar/bitstream/handle/2133/4965/relatos.pdf?sequence=3\&isAllowed=y. Acesso em: 11 set. 2020.

CANADA. Senate modernization: moving forward - Part I. 2016. Disponível em: https://sencanada.ca/content/sen/committee/421/MDRN/reports/MDRN_FINAL_FirstReport_w ebversion_e.pdf. Acesso em: 10 set. 2020.

CANNITO, Newton. A televisão na era digital: interatividade, convergência e novos modelos de negócios. São Paulo: Summus, 2010.

CARLÓN, Mário. Do cinematográfico ao televisivo: metatelevisão, linguagem e temporalidade. São Leopoldo: Ed. Unisinos, 2012.

COLEMAN, Stephen. New mediation and direct representation: reconceptualizing representation in the digital age. New Media \& Society, London, v. 7, n. 2, p. 177-198, abr. 2005.

COSSON, Rildo. Letramento político: trilhas abertas em um campo minado. E-Legis - Revista Eletrônica do Programa de Pós-Graduação da Câmara dos Deputados, Brasília, v. 4, n. 7 , p. 49-58, nov. 2011. Disponível em: http://e-legis.camara.leg.br/cefor/index.php/elegis/article/view/90/76. Acesso em: 14 nov. 2019.

CRAIN, Mark; GOFF, Brian. Televised legislatures: political information, technology, and public choice. Norwell: Kluwer Academic Publishers, 1988.

CURTIN, Deirdre; MEIJER, Albert Jacob. Does transparency strengthen legitimacy?

Information Polity, v. 11, n. 2, p. 109-122, out. 2006. Disponível em:

https://www.researchgate.net/publication/228993285_Does_Transparency_Strengthen_Legitim acy\#: :text=We $\% 20$ conclude $\% 20$ that $\% 20$ transparency $\% 20$ is,complicated $\% 20$ than $\% 20$ creating \%20fancy\%20websites. Acesso em: 14 nov. 2019.

DECLARAÇÃO PARA A ABERTURA E TRANSPARÊNCIA PARLAMENTAR. 2012. Disponível em: https://openingparliament.org/static/pdfs/portuguese.pdf. Acesso em: 14 nov. 2019. 
D'ANDRÉA, Carlos. Conexões intermidiáticas entre transmissões audiovisuais ao vivo e redes sociais online: possibilidades e tensionamentos. Revista Comunicação Midiática, Bauru, v. 10, n. 2, p. 61-75, mai./ago. 2015. Disponível em:

https://www.academia.edu/7244881/Conex\%C3\%B5es_intermidi\%C3\%A1ticas_entre_transmis s\%C3\%B5es_audiovisuais_e_redes_sociais_online_possibilidades_e_tensionamentos. Acesso em: 17 nov. 2019.

FILGUEIRAS, Fernando. Além da transparência: accountability e política da publicidade. Lua Nova, São Paulo, n. 84, p. 65-94, 2011. Disponível em:

http://www.scielo.br/scielo.php?script=sci_arttext\&pid=S0102-

64452011000300004\&lng=en\&nrm=iso. Acesso em: 14 nov. 2019.

FOX, Jonathan. Transparencia y Rendición de Cuentas. In: ACKERMAN, John (coord.). Más

Allá Del Acceso a La Información: Transparencia, Rendición De Cuentas y Estado De

Derecho. México, DF: Siglo XXI-UNAM, Instituto de Investigaciones Jurídicas-Universidad de Guadalajara-Cámara de Diputados-Centro Internacional de Estudios sobre la Transparencia y el Acceso a la Información, 2008, p. 174-198.

FREITAS, Luiz Carlos Santana de. Jornalismo legislativo: Instrumento para a Cidadania. Brasília, 2020. E-book. Disponível em: http://abcpublica.org.br/biblioteca-digital/wpcontent/uploads/2020/08/jornalismo-legislativo.pdf. Acesso em: 14 set. 2020.

GOMES, Wilson; AMORIM, Paula Karini Dias Ferreira; ALMADA, Maria Paula. Novos desafios para a ideia de transparência pública. E-Compós, v. 21, n. 2, maio/ago. 2018.

Disponível em: http://dx.doi.org/10.30962/ec.1446. Acesso em: 30 ago. 2020.

GRIFFITH, Jeffrey; LESTON-BANDEIRA, Cristina. How Are Parliaments Using New Media to Engage with Citizens? The Journal of Legislative Studies, London, v. 18, issues 3-4, p. 496-513, out. 2012.

HAJER, Maarten. Authoritative Governance: Policy-making in the age of mediatization. Oxford: Oxford University Press, 2009.

INTER-PARLIAMENTARY UNION. World e-Parliament Report 2018. 2018. E-book. Disponível em: https://www.ipu.org/resources/publications/reports/2018-11/world-eparliament-report-2018. Acesso em: 14 nov. 2019.

ITU - INTERNATIONAL TELECOMMUNICATION UNION. Measuring digital development: Facts and figures 2019. 2019. Disponível em: https://www.itu.int/en/ITUD/Statistics/Documents/facts/FactsFigures2019.pdf. Acesso em: 14 set. 2020.

LEMOS, Claudia; BARROS, Antonio; BERNARDES, Cristiane. Is a parliamentary TV channel useful for democracy? 2017. Disponível em:

https://www.panoramas.pitt.edu/larr/parliamentary-tv-channel-useful-democracy. Acesso em: 17 set. 2019.

LEÓN, Mauro Arturo Rivera. Señales abiertas, parlamentos cerrados: luces y sombras de una evaluación televisiva. In: RODRÍGUEZ, Alejandro Encinas; SALAS, Leticia (org.).

Reflexiones y propuestas ciudadanas sobre el canal de televisión del Congreso de la Unión. México, DF: Senado de La República, 2014. p. 365-390. E-book. Disponível em: http://bibliodigitalibd.senado.gob.mx/handle/123456789/2950. Acesso em: 14 nov. 2019.

LESTON-BANDEIRA, Cristina. The pursuit of legitimacy as a key driver for public engagement: the European Parliament case. Parliamentary Affairs, v. 67, issue 2, p. 415-436, abr. 2014. Disponível em:

http://eprints.whiterose.ac.uk/91192/1/Pursuit_Legitimacy_For_Public_Engagement_EP_PA_FI . Acesso em: 20 jul. 2020.

MAIA, Rousiley. Mídia e deliberação pública: mediações possíveis. In: REUNIÃO ANUAL DA COMPÓS, XI, Rio de Janeiro, 2002. Disponível em: http://www.compos.org.br/data/biblioteca_937.pdf. Acesso em: 14 set. 2020. 
MAIA, Rousiley. Mídia e vida pública - modos de abordagem. In.: MAIA, Rousiley; CASTRO, Maria Ceres Pimenta Spínola (org.). Mídia, esfera pública e identidades coletivas. Belo Horizonte: Editora UFMG, 2006.

MALAVAZI, Ademir. Manual de redação: Secretaria de Comunicação Social. Brasília: Câmara dos Deputados, 2004.

MARRIOTT, Stephanie. Live television: time, space and the broadcast event. London: SAGE Publications, 2007.

MARTÍN-BARBERO, Jesús. Dos meios às mediações: comunicação, cultura e hegemonia. Rio de Janeiro, Editora UFRJ, 1997.

MEYROWITZ, Joshua. No Sense of Place: the impact of electronic media on social Behavior. Oxford: Oxford University Press, 1985.

MICHENER, Greg; BERSCH, Katherine. Identifying transparency. Information Polity, v. 18, n. 3, p. 233-242, 2013. Disponível em: http://dx.doi.org/10.3233/ip-130299. Acesso em: 30 ago. 2020.

MIXON JR., Franklin G.; UPADHYAYA, Kamal P. Legislative television as political advertising: a public choice approach. Lincoln: iUniverse Inc., 2003.

NATIONAL DEMOCRATIC INSTITUTE FOR INTERNATIONAL AFFAIRS. Toward the development of international standards for democratic legislatures: a discussion document for review by interested legislatures, donors and international organizations. E-book. 2007. Disponível em: https://www.ndi.org/sites/default/files/2113_gov_standards_010107_5.pdf. Acesso em: 14 nov. 2019.

PÁDUA, Elisabete Matallo Marchesini de. Metodologia da pesquisa: abordagem teóricoprática. $18^{\text {a }}$ ed. E-Book. Campinas: Papirus, 2018.

RENAULT, Letícia. Comunicação e política nos canais de televisão do poder legislativo no Brasil. Belo Horizonte: Assembleia Legislativa do Estado de Minas Gerais, 2004.

RIVERA, José Antonio Aguilar. Transparencia y democracia: claves para un concierto. $4^{\mathrm{a}}$ ed. México, DF: Instituto Federal de Acceso A La Información Pública, 2008. E-book. Disponível em:

http://www.resi.org.mx/icainew_f/images/Biblioteca/Cuaderno\%20transparencia/cuadernillo10. pdf. Acesso em: 14 nov. 2019.

SANTOS, Maria de Lourdes dos. Mídia, parlamento e democracia: as TVs Legislativas como instrumento de accountability vertical no Brasil - a Câmara Municipal de Ribeirão Preto - SP. In: CONGRESSO BRASILEIRO DE CIÊNCIAS DA COMUNICAÇÃO, XXVI, Belo Horizonte, 2003. Disponível em:

http://www.intercom.org.br/papers/nacionais/2003/www/pdf/2003_NP10_santos_maria.pdf. Acesso em: 14 set. 2020.

SANTOS, Maria de Lourdes dos. TV Legislativa: TV Câmara de Ribeirão Preto e accountability. 2008. 190 f. Tese (Doutorado em Sociologia) - Faculdade de Ciências e Letras, Universidade Estadual Paulista, Araraquara, 2008.

SANT’ANNA, Francisco. Mídia das fontes: o difusor do jornalismo corporativo. 2006.

Disponível em: http://www.bocc.ubi.pt/pag/santanna-francisco-midia-fontes.pdf. Acesso em: 17 nov. 2019.

SANT'ANNA, Francisco. Mídia das fontes: um novo ator no cenário jornalístico brasileiro um olhar sobre a ação midiática do Senado Federal. Brasília: Senado Federal, 2009.

SCHEDLER, Andreas. ¿Qué es la rendición de cuentas? México, DF: Instituto Federal de Acceso a la Información Pública, 2004. E-book. Disponível em:

http://www.iepcjalisco.org.mx/sites/default/files/que_es_la_rendicion_de_cuentas.pdf. Acesso em: 14 nov. 2019. 
SURYADJAJA, Jennifer. The impact of selfie journalism: selfies in the world of news and how it impacts the world of reporting. 2016. Disponível em:

https://medium.com/@qriouskid/selfie-journalism-and-its-grand-impact-e64f65d519a1. Acesso em: 17 nov. 2019.

URBINATI, Nadia. Crise e metamorfoses da democracia. Revista Brasileira de Ciências Sociais, v. 28, n. 82, p. 5-16, jun. 2013. Disponível em:

https://www.scielo.br/pdf/rbcsoc/v28n82/v28n82a01.pdf. Acesso em: 30 ago. 2020.

VERÓN, Eliseo. Teoria da midiatização: uma perspectiva semioantropológica e algumas de suas consequências. Matrizes, São Paulo, v. 8, n. 1, p. 13-19, jan./jun. 2014. Disponível em: http://www.revistas.usp.br/matrizes/article/view/82928. Acesso em: 19 nov. 2019.

YIN, Robert K. Pesquisa qualitativa do início ao fim. E-Book. Porto Alegre: Penso, 2016. 
Ginny Carla Morais de Carvalho, Claudia Regina Fonseca Lemos

APÊNDICE A - Critérios considerados na observação direta

\begin{tabular}{|c|c|c|}
\hline & Critério & O que foi observado \\
\hline \multirow{5}{*}{ TV } & Canal próprio & $\begin{array}{l}\text { Se o Legislativo possui canal de televisão dedicado e de gestão } \\
\text { própria. }\end{array}$ \\
\hline & $\begin{array}{l}\text { Canal dedicado gerido por } \\
\text { terceiros }\end{array}$ & $\begin{array}{l}\text { Se o Legislativo possui canal de televisão dedicado às atividades } \\
\text { parlamentares, mas sob gestão de terceiros. }\end{array}$ \\
\hline & TV aberta & Se o sinal do canal televisivo é aberto e gratuito. \\
\hline & TV fechada & $\begin{array}{l}\text { Se o sinal do canal televisivo é transmitido em sinal de satélite, cabo } \\
\text { ou outras formas que exigem assinatura ou pagamento por parte do } \\
\text { público. }\end{array}$ \\
\hline & Vivo TV & $\begin{array}{l}\text { Se a sessão plenária é transmitida ao vivo, em vídeo, por canal de } \\
\text { televisão. }\end{array}$ \\
\hline \multirow{7}{*}{ Site } & Site oficial & Endereço do site oficial do Legislativo. \\
\hline & Agenda prévia & $\begin{array}{l}\text { Se há divulgação prévia da data e horário da próxima sessão plenária } \\
\text { no site oficial do parlamento. }\end{array}$ \\
\hline & Vivo no site & $\begin{array}{l}\text { Se a sessão plenária é transmitida ao vivo, em vídeo, diretamente pelo } \\
\text { site oficial do Legislativo ou por algum link redirecionado pelo } \\
\text { mesmo, desde que esteja visível e claro que, ao clicar em determinado } \\
\text { lugar, você será direcionado à sessão ou à TV legislativa ao vivo. }\end{array}$ \\
\hline & Íntegra gravada no site & $\begin{array}{l}\text { Se a gravação, em vídeo, na íntegra, da sessão plenária fica disponível } \\
\text { no site oficial do Legislativo. }\end{array}$ \\
\hline & Notícias no site & Se o site divulga reportagem escrita com resultado da sessão plenária. \\
\hline & Tempo real da sessão & $\begin{array}{l}\text { Se o site divulga, em tempo real, notas ou reportagens em texto, } \\
\text { informando o que está acontecendo no plenário. }\end{array}$ \\
\hline & Web TV & $\begin{array}{l}\text { Se o site possui televisão com programação } 24 \text { horas dedicada ao } \\
\text { Legislativo. }\end{array}$ \\
\hline \multirow{3}{*}{$\begin{array}{l}\text { YouTube e } \\
\quad \text { Vimeo }\end{array}$} & Perfil & Endereço da conta oficial do Legislativo no Youtube e no Vimeo. \\
\hline & Vivo & $\begin{array}{l}\text { Se a sessão plenária é transmitida ao vivo, em vídeo, por conta no } \\
\text { YouTube e no Vimeo. }\end{array}$ \\
\hline & Íntegra gravada & $\begin{array}{l}\text { Se a gravação, em vídeo, na íntegra, da sessão plenária fica disponível } \\
\text { em canal no YouTube e no Vimeo. }\end{array}$ \\
\hline
\end{tabular}


Plenários ao vivo: um mapeamento das transmissões dos legislativos do continente americano

\begin{tabular}{|c|c|c|}
\hline \multirow{8}{*}{$\begin{array}{l}\text { Mídias } \\
\text { Sociais }\end{array}$} & Facebook & Endereço da conta oficial do Legislativo no Facebook. \\
\hline & Twitter & Endereço da conta oficial do Legislativo no Twitter. \\
\hline & Instagram & Endereço da conta oficial do Legislativo no Instagram. \\
\hline & Reportagens & $\begin{array}{l}\text { Se há publicação de reportagens com o resultado da sessão plenária } \\
\text { nas mídias sociais analisadas. }\end{array}$ \\
\hline & Trechos em vídeo & $\begin{array}{l}\text { Se há publicação de trechos da sessão plenária em vídeo nas mídias } \\
\text { sociais analisadas. }\end{array}$ \\
\hline & Tempo real da sessão & $\begin{array}{l}\text { Se as mídias sociais analisadas divulgam, em tempo real, notas ou } \\
\text { reportagens em texto, informando o que está acontecendo na sessão. }\end{array}$ \\
\hline & Vivo da sessão & $\begin{array}{l}\text { Se as mídias sociais analisadas fazem a transmissão ao vivo em vídeo } \\
\text { da sessão plenária diretamente de tais mídias, usando ferramentas } \\
\text { como Periscope, Facebook Live ou IGTV. }\end{array}$ \\
\hline & Íntegra da sessão & $\begin{array}{l}\text { Se a gravação, em vídeo, na íntegra, da sessão plenária fica disponíve } \\
\text { nas mídias sociais analisadas. }\end{array}$ \\
\hline \multirow{4}{*}{ Vídeo e áudio } & Câmeras & $\begin{array}{l}\text { Se a captação de imagens da transmissão ao vivo é feita por câmeras } \\
\text { fixas ou móveis e localização delas dentro do plenário. }\end{array}$ \\
\hline & Enquadramento & Padrões de enquadramento de imagem da transmissão ao vivo. \\
\hline & Microfones & $\begin{array}{l}\text { Se a captação de áudio é feita por microfones próprios ou som } \\
\text { ambiente e de quem é o controle sobre a palavra. }\end{array}$ \\
\hline & Libras & Se a transmissão insere a imagem de intérprete de língua de sinais. \\
\hline \multirow{3}{*}{$\begin{array}{l}\text { Informações } \\
\text { adicionais }\end{array}$} & Explicações escritas & $\begin{array}{l}\text { Padrões de informações inseridas em tela na transmissão ao vivo em } \\
\text { vídeo. }\end{array}$ \\
\hline & Explicações faladas & Padrões de informações faladas na transmissão ao vivo em vídeo. \\
\hline & Jornalista & Padrões de inserção de jornalistas na tela na transmissão ao vivo. \\
\hline
\end{tabular}

Fonte: Elaboração própria (2020).

Artigo submetido em: 2021-04-26

Artigo reapresentado em: 2021-05-16

Artigo aceito em: 2021-05-17 